CRYSTALLOGRAPHIC COMMUNICATIONS

ISSN 2056-9890

Received 3 December 2019

Accepted 17 December 2019

Edited by A. J. Lough, University of Toronto, Canada

Keywords: crystal structure; dihydrobenzodiazole; hydrogen bond; triazole; $\pi$-stacking; Hirshfeld surface.

CCDC reference: 1972575

Supporting information: this article has supporting information at journals.iucr.org/e

\section{Crystal structure, Hirshfeld surface analysis and DFT studies of 1-benzyl-3-[(1-benzyl-1H-1,2,3- triazol-5-yl)methyl]-2,3-dihydro-1H-1,3-benzo- diazol-2-one monohydrate}

\author{
Asmaa Saber, ${ }^{a}$ Nada Kheira Sebbar, ${ }^{b, a *}$ Tuncer Hökelek, ${ }^{c}$ Mohamed Labd Taha, \\ Joel T. Mague, ${ }^{d}$ Noureddine Hamou Ahabchane ${ }^{\mathrm{a}}$ and El Mokhtar Essassi ${ }^{\mathrm{a}}$
}

aLaboratoire de Chimie Organique Hétérocyclique URAC 21, Pôle de Compétence Pharmacochimie, Av. Ibn Battouta, BP 1014, Faculté des Sciences, Université Mohammed V, Rabat, Morocco, 'baboratoire de Chimie Appliquée et Environnement, Equipe de Chimie Bioorganique Appliquée, Faculté des Sciences, Université Ibn Zohr, Agadir, Morocco, ${ }^{\mathbf{c}}$ Department of Physics, Hacettepe University, 06800 Beytepe, Ankara, Turkey, and ${ }^{\mathbf{d}}$ Department of Chemistry, Tulane University, New Orleans, LA 70118, USA. *Correspondence e-mail: nadouchsebbarkheira@gmail.com

In the title molecule, $\mathrm{C}_{24} \mathrm{H}_{21} \mathrm{~N}_{5} \mathrm{O} \cdot \mathrm{H}_{2} \mathrm{O}$, the dihydrobenzodiazole moiety is not quite planar, while the whole molecule adopts a U-shaped conformation in which there is a close approach of the two benzyl groups. In the crystal, chains of alternating molecules and lattice water extending along [201] are formed by $\mathrm{O}-$ $\mathrm{H}_{\text {UncoordW }} \cdot \mathrm{O}_{\text {Dhyr }}$ and $\mathrm{O}-\mathrm{H}_{\text {UncoordW }} \cdots \mathrm{N}_{\text {Trz }}$ (UncoordW $=$ uncoordinated water, Dhyr $=$ dihydro and $\operatorname{Trz}=$ triazole) hydrogen bonds. The chains are connected into layers parallel to $(010)$ by $\mathrm{C}-\mathrm{H}_{\mathrm{Trz}} \cdots \mathrm{O}_{\text {Uncoordw }}$ hydrogen bonds with the dihydrobenzodiazole units in adjacent layers intercalating to form head-to-tail $\pi$-stacking [centroid-to-centroid distance $=3.5694$ (11) $\AA$ ] interactions between them, which generates the overall three-dimensional structure. Hirshfeld surface analysis indicates that the most important contributions for the crystal packing are from $\mathrm{H} \cdots \mathrm{H}(52.1 \%), \mathrm{H} \cdots \mathrm{C} / \mathrm{C} \cdots \mathrm{H}(23.8 \%)$ and $\mathrm{O} \cdots \mathrm{H} /$ $\mathrm{H}$... O (11.2\%) interactions. Hydrogen-bonding and van der Waals interactions are the dominant interactions in the crystal packing. Density functional theory (DFT) optimized structures at the B3LYP/ 6-311 G(d,p) level are compared with the experimentally determined molecular structure in the solid state. The HOMO-LUMO behaviour was elucidated to determine the energy gap.

\section{Chemical context}

Nitrogen heterocyclic compounds are known to exhibit excellent biological and pharmaceutical activities (Olesen et al., 1994; Baxter \& Clarke, 1992; Saber et al., 2020; Rémond et $a l ., 1997)$. The benzimidazole core has several active sites and provides great responsiveness, making it an excellent heterocyclic precursor in the syntheses of the new heterocyclic compounds (Saber et al., 2018a,b; Ouzidan et al., 2011; Saber et al., 2020). With respect to the biological applications of benzimidazolone derivatives, it has been shown that these compounds are found to possess potent antioxidant (Gaba et al., 2014), antiparasitic (Ayhan-Kılcıgil et al., 2007), anthelmintic (Navarrete-Vazquez et al., 2001), antiproliferative (Ravina et al., 1993), anti-HIV (Garuti et al., 2000), anticonvulsant (Rao et al., 2002), anti-inflammatory (Thakurdesai et al., 2007), antihypertensive (Serafin et al., 1989) and antitrichinellosis (Mavrova et al., 2007) activities. In addition, they are considered to be important moieties for the development of molecules of pharmaceutical interest (Mondieig et al., 2013; 
Lakhrissi et al., 2008). As a continuation of our research devoted to the study of the cycloaddition reactions involving benzimidazolone derivatives (Sebbar et al., 2016; Saber et al., 2020), we report herein the synthesis, the molecular and crystal structures of the title compound along with the results of the Hirshfeld surface analysis and the density functional theory (DFT) computational calculations carried out at the B3LYP/6-311 G(d,p) level in order to compare the theoretical and experimentally determined molecular structures in the solid state.

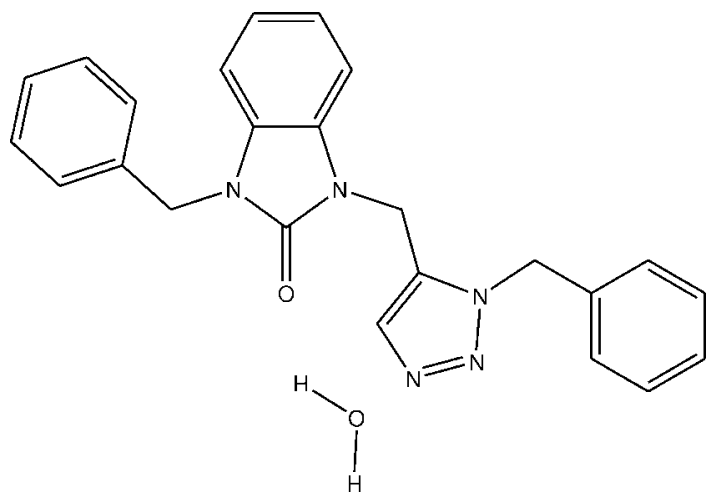

\section{Structural commentary}

The title molecule, (I), adopts a U-shaped conformation with an $\mathrm{H} 20 \cdots \mathrm{C} 14$ separation of $2.83 \AA$, which is very close to a normal van der Waals contact $(2.90 \AA)$. The orientation of the C11-C17 benzyl group is partly determined by an intramolecular $\mathrm{C} 13-\mathrm{H} 13 \cdots \mathrm{Cg}$ interaction, where $\mathrm{Cg}$ is the centroid of the triazole (C9/C10/N3-N5), ring $C$ (Fig. 1 and Table 1). The dihydrobenzodiazole unit is not quite planar, as

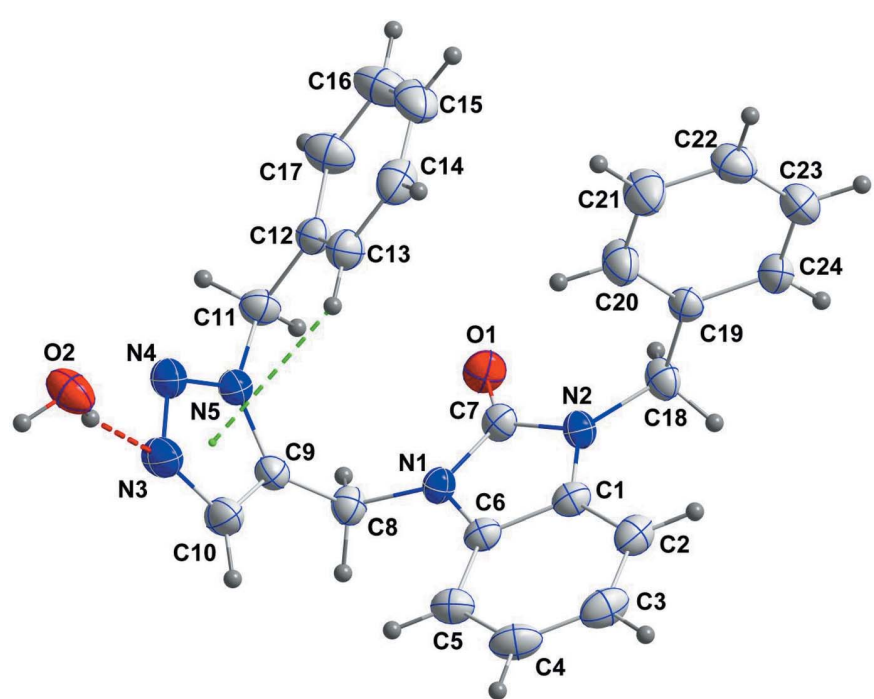

Figure 1

The molecular structure of the title compound with the atom-numbering scheme. Displacement ellipsoids are drawn at the $50 \%$ probability level. The $\mathrm{O}-\mathrm{H}_{\text {UncoordW }} \cdots \mathrm{N}_{\mathrm{Trz}}$ (UncoordW $=$ uncoordinated water, $\operatorname{Trz}=$ triazole) hydrogen bond is shown by a red dashed line while the intramolecular $\mathrm{C}-\mathrm{H} \cdots \pi($ ring) interaction is depicted by a green dashed line.

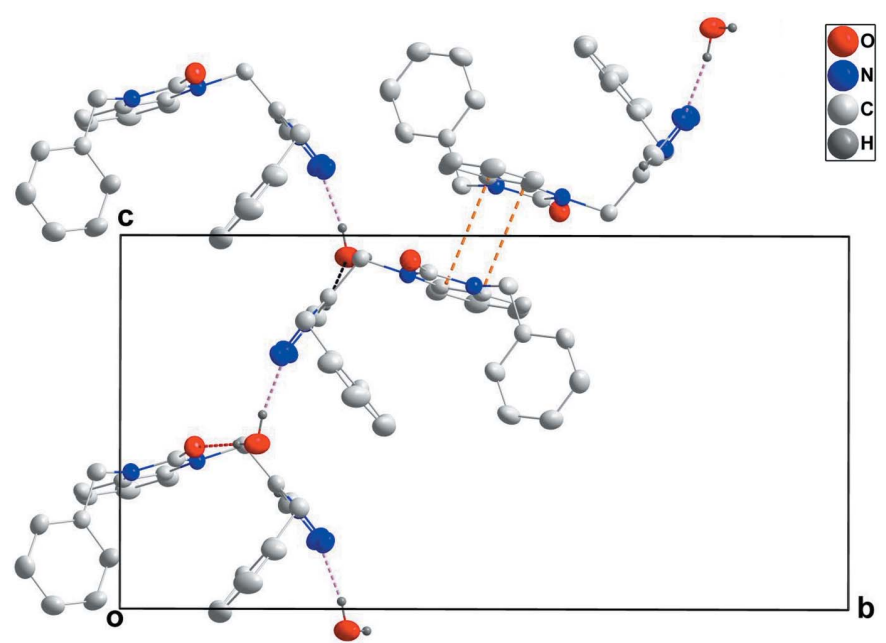

Figure 2

A partial packing diagram viewed along the $a$-axis direction with $\mathrm{O}-$ $\mathrm{H}_{\text {Uncoordw }} \cdots \mathrm{O}_{\text {Dhyr }}, \quad \mathrm{O}-\mathrm{H}_{\text {Uncoordw }} \cdots \mathrm{N}_{\text {Trz }}$ and $\mathrm{C}-\mathrm{H}_{\text {Trz }} \cdots \mathrm{O}_{\text {UncoordW }}$ (UncoordW $=$ uncoordinated water, Dhyr $=$ dihydro, $\operatorname{Trz}=$ triazole $)$ hydrogen bonds shown, respectively, as red, pink and black dashed lines. The $\pi$-stacking interactions are shown as orange dashed lines.

indicated by the dihedral angle of $2.50(8)^{\circ}$ between the constituent rings $A(\mathrm{C} 1-\mathrm{C} 6)$ and $B(\mathrm{~N} 1 / \mathrm{N} 2 / \mathrm{C} 1 / \mathrm{C} 6 / \mathrm{C} 7)$ and the deviation of atom C7 by 0.0418 (14) $\AA$ out of the mean plane through the whole unit. The benzene ring $D(\mathrm{C} 12-\mathrm{C} 17)$ is inclined to the triazole ring $C$ by $78.91(11)^{\circ}$ while the latter ring is inclined to the $B$ ring by $64.70(11)^{\circ}$. The dihedral angle between the mean planes of the $B$ and $E(\mathrm{C} 19-\mathrm{C} 24)$ rings is $87.67(8)^{\circ}$.

\section{Supramolecular features}

In the crystal, the molecules form chains with the water molecule of crystallization, which extend along [201] through $\mathrm{O}-$ $\mathrm{H}_{\text {UncoordW }} \cdots \mathrm{O}_{\text {Dhyr }}$ and $\mathrm{O}-\mathrm{H}_{\text {UncoordW }} \cdots \mathrm{N}_{\text {Trz }}$ (UncoordW $=$ uncoordinated water, Dhyr $=$ dihydro, $\operatorname{Trz}=$ triazole) hydrogen bonds (Table 1 and Fig. 2). The chains are connected

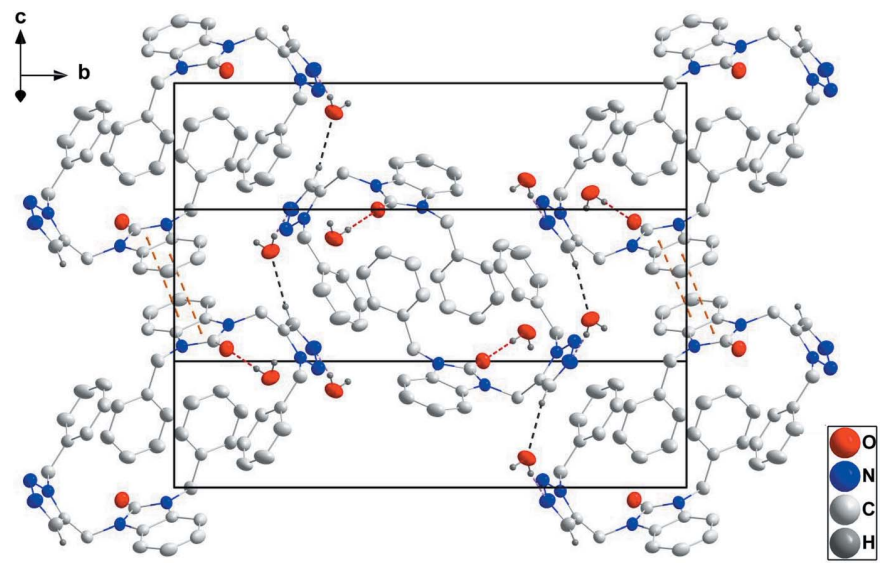

Figure 3

A partial packing diagram projected onto (301) with intermolecular interactions depicted as in Fig. 2. 
Table 1

Hydrogen-bond geometry $\left(\AA,^{\circ}\right)$.

$C g$ is the centroid of the triazole ring $C(\mathrm{C} 9 / \mathrm{C} 10 / \mathrm{N} 3-\mathrm{N} 5)$.

\begin{tabular}{lllll}
\hline$D-\mathrm{H} \cdots A$ & $D-\mathrm{H}$ & $\mathrm{H} \cdots A$ & $D \cdots A$ & $D-\mathrm{H} \cdots A$ \\
\hline $\mathrm{O} 2-\mathrm{H} 2 A \cdots \mathrm{N} 3$ & 0.87 & 2.04 & $2.892(2)$ & 166 \\
$\mathrm{O} 2-\mathrm{H} 2 B \cdots \mathrm{O} 1^{\mathrm{i}}$ & 0.87 & 2.00 & $2.865(2)$ & 176 \\
$\mathrm{C} 10-\mathrm{H} 10 \cdots \mathrm{O} 2^{\mathrm{v}}$ & 0.95 & 2.48 & $3.402(3)$ & 164 \\
$\mathrm{C} 13-\mathrm{H} 13 \cdots C g$ & 0.95 & 2.83 & $3.451(3)$ & 124 \\
\hline
\end{tabular}

Symmetry codes: (i) $x-1,-y+\frac{1}{2}, z-\frac{1}{2}$; (v) $x,-y+\frac{1}{2}, z+\frac{1}{2}$.

into layers parallel to (010) by $\mathrm{C}-\mathrm{H}_{\mathrm{Trz}} \cdots \mathrm{O}_{\text {Uncoordw }}$ hydrogen bonds (Table 1 and Fig. 2). Intercalation of the dihydrobenzodiazole groups between adjacent layers with concomitant head-to-tail $\pi$-stacking interactions between them $\left[C g 2 \cdots C g 1^{\mathrm{i}}=3.5694(11) \AA\right.$ where $C g 1$ and $C g 2$ are the centroids of the $A$ and $B$ rings, respectively; symmetry code: (i) $-x+1,-y+1,-z+2$; dihedral angle $\left.=2.50(10)^{\circ}\right]$ leads to the final three-dimensional structure (Fig. 3).

\section{Hirshfeld surface analysis}

In order to visualize the intermolecular interactions in the crystal of the title compound, a Hirshfeld surface (HS) analysis (Hirshfeld, 1977; Spackman \& Jayatilaka, 2009) was carried out using Crystal Explorer 17.5 (Turner et al., 2017). In the HS plotted over $d_{\text {norm }}$ (Fig. 4), white areas indicates contacts with distances equal to the sum of van der Waals radii, and the red and blue colours indicate distances shorter (in close contact) or longer (distinct contact), respectively, than the van der Waals radii (Venkatesan et al., 2016). The bright-red spots appearing near $\mathrm{O} 1$ and hydrogen atom $\mathrm{H} 2 B$ indicate their roles as the respective donors and acceptors. The shape-index of the HS is a tool to visualize the $\pi-\pi$ stacking by

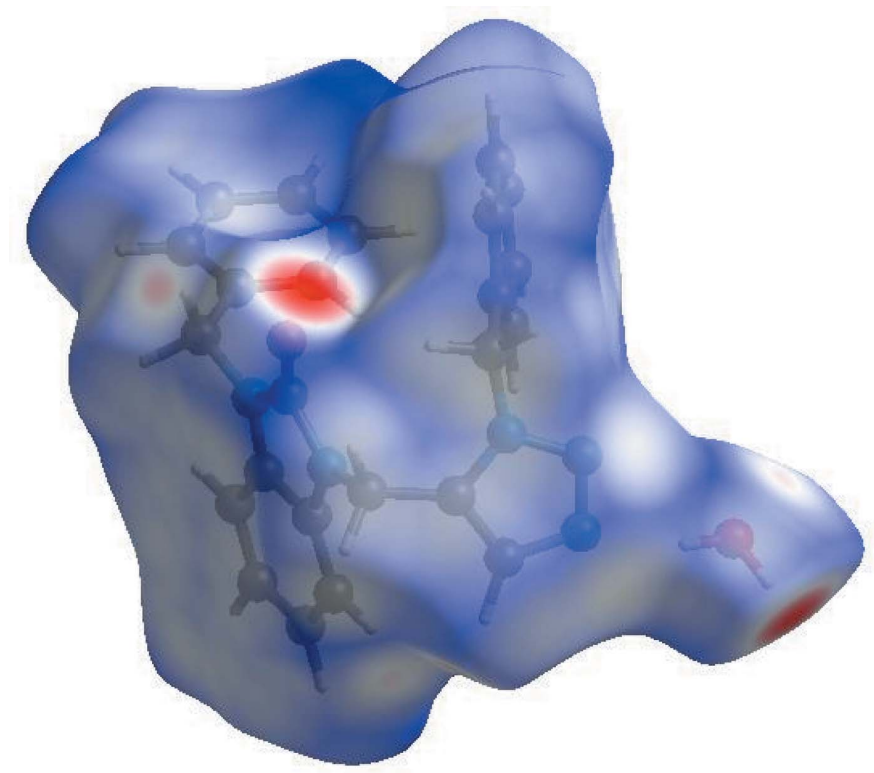

Figure 4

View of the three-dimensional Hirshfeld surface of the title compound plotted over $d_{\text {norm }}$ in the range -0.5603 to 1.3285 a.u.
Table 2

Selected interatomic distances $(\AA)$.

\begin{tabular}{llll}
\hline $\mathrm{O} 2 \cdots \mathrm{O} 1^{\mathrm{i}}$ & $2.865(2)$ & $\mathrm{C} 10 \cdots \mathrm{H} 5$ & 2.98 \\
$\mathrm{O} 2 \cdots \mathrm{C} 17^{\mathrm{i}}$ & $3.192(3)$ & $\mathrm{C} 11 \cdots \mathrm{H} 8 B$ & 2.90 \\
$\mathrm{O} 2 \cdots \mathrm{N} 3$ & $2.892(2)$ & $\mathrm{C} 14 \cdots \mathrm{H} 20$ & 2.83 \\
$\mathrm{O} 1 \cdots \mathrm{H} 8 B$ & 2.55 & $\mathrm{C} 18 \cdots \mathrm{H} 2$ & 2.98 \\
$\mathrm{O} 1 \cdots \mathrm{H} 11 B$ & 2.81 & $\mathrm{C} 22 \cdots \mathrm{H} 16^{\text {vii }}$ & 2.98 \\
$\mathrm{O} 1 \cdots \mathrm{H} 18 A$ & 2.56 & $\mathrm{C} 22 \cdots \mathrm{H} 13^{\text {vi }}$ & 2.97 \\
$\mathrm{O} 1 \cdots \mathrm{H} 18 A^{\mathrm{ii}}$ & 2.87 & $\mathrm{C} 23 \cdots \mathrm{H} 16^{\text {vii }}$ & 2.97 \\
$\mathrm{O} 2 \cdots \mathrm{H} 5^{\mathrm{iii}}$ & 2.64 & $\mathrm{H} 2 \cdots \mathrm{N} 4^{\text {viii }}$ & 2.78 \\
$\mathrm{O} 2 \cdots \mathrm{H} 11 B^{\mathrm{i}}$ & 2.77 & $\mathrm{H} 2 A \cdots \mathrm{N} 4$ & 2.62 \\
$\mathrm{O} 2 \cdots \mathrm{H} 17^{\mathrm{i}}$ & 2.71 & $\mathrm{H} 2 A \cdots \mathrm{N} 3$ & 2.04 \\
$\mathrm{~N} 4 \cdots \mathrm{C} 13$ & $3.200(3)$ & $\mathrm{H} 2 B \cdots \mathrm{O} 1^{\mathrm{i}}$ & 2.00 \\
$\mathrm{~N} 2 \cdots \mathrm{H} 20$ & 2.60 & $\mathrm{H} 2 B \cdots \mathrm{H} 11 B^{\mathrm{i}}$ & 2.48 \\
$\mathrm{~N} 4 \cdots \mathrm{H} 13$ & 2.73 & $\mathrm{H} 3 \cdots \mathrm{H} 15^{\mathrm{vi}}$ & 2.48 \\
$\mathrm{~N} 5 \cdots \mathrm{H} 13$ & 2.52 & $\mathrm{H} 4 \cdots \mathrm{H} 18 A^{\mathrm{ix}}$ & 2.57 \\
$\mathrm{C} 1 \cdots \mathrm{C} 20$ & $3.557(3)$ & $\mathrm{H} 5 \cdots \mathrm{H} 10$ & 2.44 \\
$\mathrm{C} 2 \cdots \mathrm{C} 6^{\text {iv }}$ & $3.542(3)$ & $\mathrm{H} 8 A \cdots \mathrm{N} 4^{\mathrm{v}}$ & 2.67 \\
$\mathrm{C} 3 \cdots \mathrm{C} 7^{\mathrm{iv}}$ & $3.540(3)$ & $\mathrm{H} 8 B \cdots \mathrm{H} 11 B$ & 2.27 \\
$\mathrm{C} 5 \cdots \mathrm{C} 9$ & $3.592(3)$ & $\mathrm{H} 10 \cdots \mathrm{O} 2^{\mathrm{v}}$ & 2.48 \\
$\mathrm{C} 9 \cdots \mathrm{C} 5$ & $3.592(3)$ & $\mathrm{H} 10 \cdots \mathrm{H} 17^{\mathrm{ix}}$ & 2.46 \\
$\mathrm{C} 10 \cdots \mathrm{O} 2^{\mathrm{v}}$ & $3.402(3)$ & $\mathrm{H} 11 A \cdots \mathrm{C} 15^{\mathrm{v}}$ & 2.92 \\
$\mathrm{C} 11 \cdots \mathrm{C} 15^{\mathrm{v}}$ & $3.421(3)$ & $\mathrm{H} 11 A \cdots \mathrm{H} 17$ & 2.51 \\
$\mathrm{C} 14 \cdots \mathrm{C} 20$ & $3.505(3)$ & $\mathrm{H} 16 \cdots \mathrm{H} 23^{\mathrm{vii}}$ & 2.44 \\
$\mathrm{C} 2 \cdots \mathrm{H} 18 B$ & 2.98 & $\mathrm{H} 16 \cdots \mathrm{H} 22^{\mathrm{vii}}$ & 2.46 \\
$\mathrm{C} 3 \cdots \mathrm{H} 15^{\mathrm{vi}}$ & 2.88 & $\mathrm{H} 18 A \cdots \mathrm{H} 18 A^{\mathrm{ii}}$ & 2.19 \\
$\mathrm{C} 8 \cdots \mathrm{H} 11 B$ & 2.79 & $\mathrm{H} 18 B \cdots \mathrm{H} 24$ & 2.43 \\
$\mathrm{C} 8 \cdots \mathrm{H} 5$ & 2.99 & $\mathrm{H} 24 \cdots \mathrm{N} 3^{\text {viii }}$ & 2.76 \\
\hline
\end{tabular}

Symmetry codes: (i) $\quad x-1,-y+\frac{1}{2}, z-\frac{1}{2} ; \quad$ (ii) $\quad-x+2,-y+1,-z+2$; $\quad$ (iii) $x,-y+\frac{1}{2}, z-\frac{1}{2} ; \quad$ (iv) $\quad-x+1,-y+1,-z+2 ; \quad$ (v) $\quad x,-y+\frac{1}{2}, z+\frac{1}{2}$; $\quad$ (vi)

the presence of adjacent red and blue triangles; if there are no adjacent red and/or blue triangles, then there are no $\pi-\pi$ interactions. Fig. 5 clearly suggests that there are $\pi-\pi$ interactions in (I).

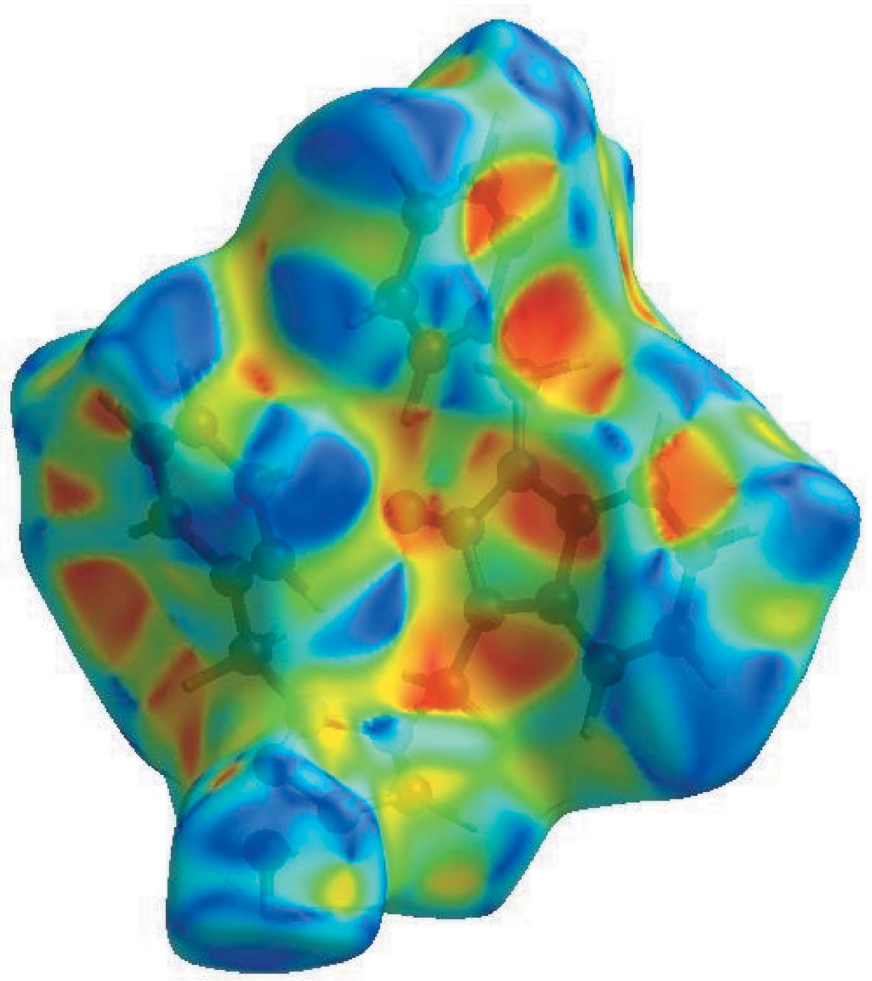

Figure 5

Hirshfeld surface of the title compound plotted over shape-index. 

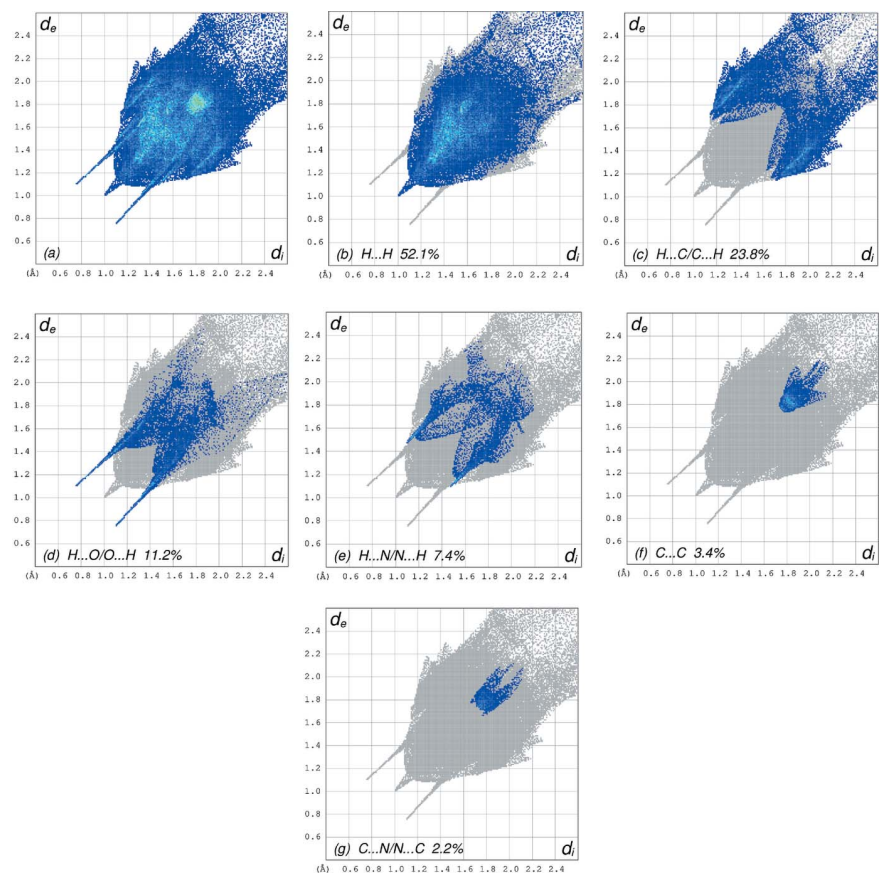

Figure 6

The full two-dimensional fingerprint plots for the title compound, showing (a) all interactions, and delineated into $(b) \mathrm{H} \cdots \mathrm{H},(c) \mathrm{H} \cdots \mathrm{Cl}$ $\mathrm{C} \cdots \mathrm{H},(d) \mathrm{H} \cdots \mathrm{O} / \mathrm{O} \cdots \mathrm{H},(e) \mathrm{H} \cdots \mathrm{N} / \mathrm{N} \cdots \mathrm{H},(f) \mathrm{C} \cdots \mathrm{C}$ and $(g) \mathrm{C} \cdots \mathrm{N} /$ $\mathrm{N} \cdots \mathrm{C}$ interactions. The $d_{\mathrm{i}}$ and $d_{\mathrm{e}}$ values are the closest internal and external distances (in $\AA$ ) from given points on the Hirshfeld surface contacts.

The overall two-dimensional fingerprint plot, Fig. $6 a$, and those delineated into $\mathrm{H} \cdots \mathrm{H}, \mathrm{H} \cdots \mathrm{C} / \mathrm{C} \cdots \mathrm{H}, \mathrm{H} \cdots \mathrm{O} / \mathrm{O} \cdots \mathrm{H}$, $\mathrm{H} \cdots \mathrm{N} / \mathrm{N} \cdots \mathrm{H}, \mathrm{C} \cdots \mathrm{C}$ and $\mathrm{C} \cdot \mathrm{N} / \mathrm{N} \cdots \mathrm{C}$ contacts (McKinnon et $a l ., 2007)$ are illustrated in Fig. $6 b-g$, respectively, together with their relative contributions to the Hirshfeld surface. The most important interaction (Table 2) is $\mathrm{H} \cdots \mathrm{H}$, contributing $52.1 \%$ to the overall crystal packing, which is reflected in Fig. $6 b$ as widely scattered points of high density due to the large hydrogen content of the molecule with the tip at $d_{\mathrm{e}}=d_{\mathrm{i}}=$ $1.00 \AA$. The presence of $\mathrm{C}-\mathrm{H} \cdots \pi$ interactions give rise to pairs of characteristic wings in the fingerprint plot delineated into $\mathrm{H} \cdots \mathrm{C} / \mathrm{C} \cdots \mathrm{H}$ contacts $(23.8 \%$ contribution to the $\mathrm{HS})$, Fig. $6 c$,(Table 2) with triple pairs of spikes with the tips at $d_{\mathrm{e}}+$ $d_{\mathrm{i}}=2.86,2.82$ and $2.85 \AA$. The scattered points in the pair of wings in the fingerprint plots delineated into $\mathrm{H} \cdots \mathrm{O} / \mathrm{O} \cdots \mathrm{H}$ contacts $(11.2 \%$ contribution), Fig. $6 d$, have a symmetrical distribution with the edges at $d_{\mathrm{e}}+d_{\mathrm{i}}=1.85 \AA$. The H.N/ $\mathrm{N} \cdot \mathrm{N}$ contacts, contributing $7.4 \%$ to the overall crystal packing, are shown in Fig. $6 e$ as widely scattered points with the tips at $d_{\mathrm{e}}+d_{\mathrm{i}}=2.56 \AA$. The C . C contacts, Fig. $6 f$, have an arrow-shaped distribution of points with the tip at $d_{\mathrm{e}}=d_{\mathrm{i}}=$ $1.77 \AA$. Finally, the C $\cdots \mathrm{N} / \mathrm{N} \cdots \mathrm{C}$ interactions $(2.2 \%)$ are reflected in Fig. $6 g$ as tiny characteristic wings with the tips at $d_{\mathrm{e}}+d_{\mathrm{i}}=3.44 \AA$ А.

The Hirshfeld surface representations with the function $d_{\text {norm }}$ plotted onto the surface are shown for the $\mathrm{H} \cdots \mathrm{H}$, $\mathrm{H} \cdots \mathrm{C} / \mathrm{C} \cdots \mathrm{H}, \mathrm{H} \cdots \mathrm{O} / \mathrm{O} \cdots \mathrm{H}$ and $\mathrm{H} \cdots \mathrm{N} / \mathrm{N} \cdots \mathrm{H}$ interactions in Fig. $7 a-d$, respectively.

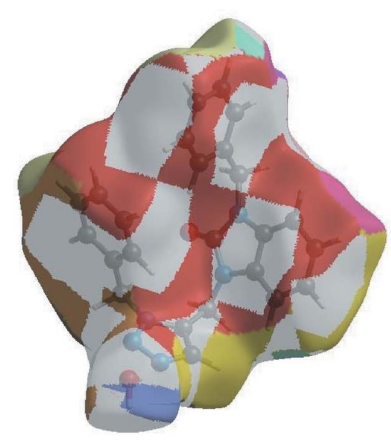

(a)

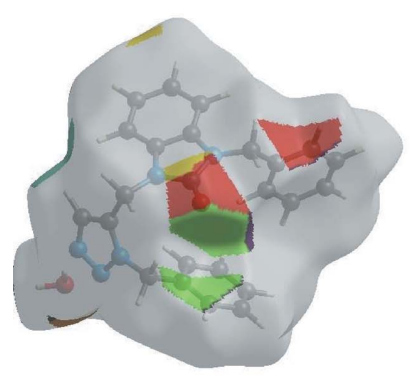

(c)

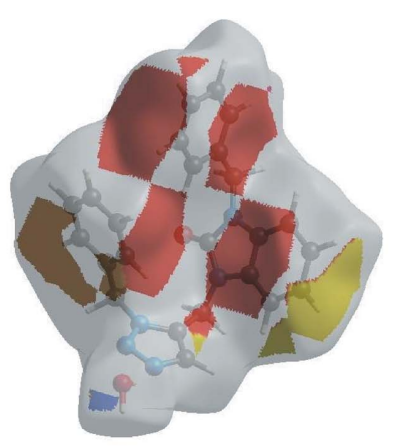

(b)

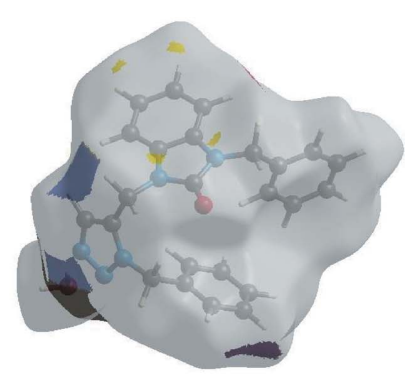

(d)
Figure 7

The Hirshfeld surface representations with the function $d_{\text {norm }}$ plotted onto the surface for $(a) \mathrm{H} \cdots \mathrm{H},(b) \mathrm{H} \cdots \mathrm{C} / \mathrm{C} \cdots \mathrm{H},(c) \mathrm{H} \cdots \mathrm{O} / \mathrm{O} \cdots \mathrm{H}$ and (d) $\mathrm{H} \cdots \mathrm{N} / \mathrm{N} \cdots \mathrm{H}$ interactions.

The Hirshfeld surface analysis confirms the importance of $\mathrm{H}$-atom contacts in establishing the packing. The large number of $\mathrm{H} \cdots \mathrm{H}, \mathrm{H} \cdots \mathrm{C} / \mathrm{C} \cdots \mathrm{H}$ and $\mathrm{H} \cdots \mathrm{O} / \mathrm{O} \cdots \mathrm{H}$ interactions suggest that van der Waals interactions and hydrogen bonding play the major roles in the crystal packing (Hathwar et al., 2015).

\section{Database survey}

An N-substituted benzoimidazol-2-one analogue (Saber et al., 2018a,b; Saber et al., 2020) and other similar compounds have also been reported (Belaziz et al., 2012, 2013; Bouayad et al., 2015). In derivatives of benzimidazolin-2-one in which both nitrogen atoms form exocyclic $\mathrm{C}-\mathrm{N}$ bonds, the bicyclic ring system is either planar, has a slight twist end-to-end, or, in the cases where the exocyclic substituents form a ring, has a very shallow bowl shape. The closest examples to the title compound are 2 (Saber et al., 2018a) and 3 (Saber et al., 2018b) with 4 (Díez-Barra et al., 1997) as a more distant relative. In 3, the $\mathrm{C}-\mathrm{N}$ bond, connecting the nitrogen atoms to form exocyclic units are 1.4632 (15) and 1.4525 (16) $\AA$, while in the title compound, the $\mathrm{C}-\mathrm{N}$ bonds are 1.4301 (15) and 1.4525 (16) $\AA$. In the bicyclic units, they are in an antiarrangement, and this is basically the same for $\mathbf{2}$. Interestingly, the three bicyclic units in $\mathbf{4}$ are close to all being syn to one another. 


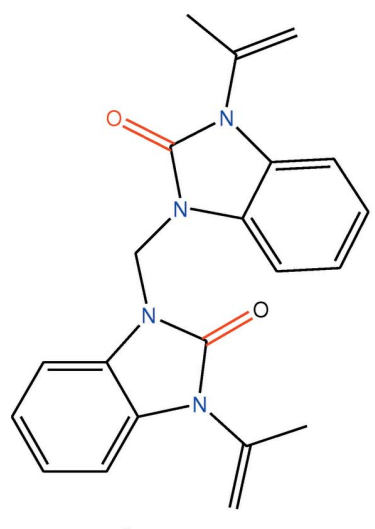

2

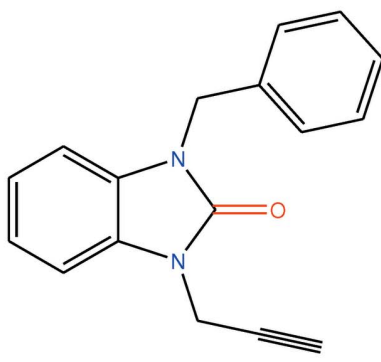

3

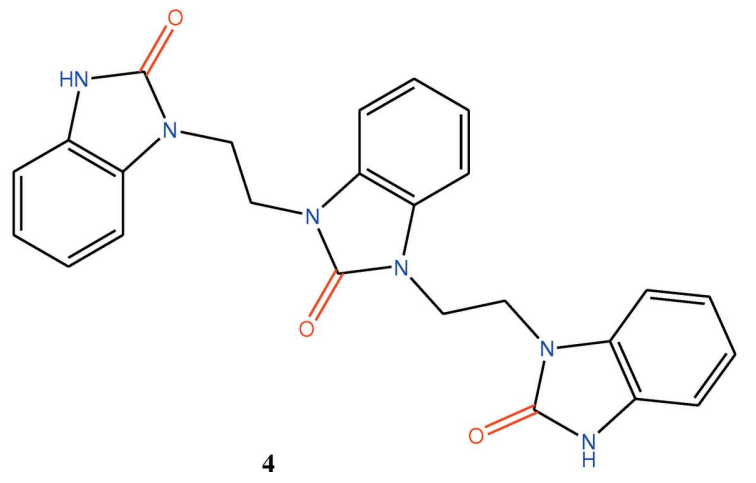

\section{DFT calculations}

The optimized structure of the title compound, (I), in the gas phase was generated theoretically via density functional theory (DFT) using standard B3LYP functional and 6$311 \mathrm{G}(\mathrm{d}, \mathrm{p})$ basis-set calculations (Becke, 1993) as implemented in GAUSSIAN 09 (Frisch et al., 2009). The theoretical and experimental results are in good agreement (Table 3 ). The highest-occupied molecular orbital (HOMO), acting as an electron donor, and the lowest-unoccupied molecular orbital (LUMO), acting as an electron acceptor, are very important parameters for quantum chemistry. When the energy gap is small, the molecule is highly polarizable and has high chemical reactivity. The DFT calculations provide some important information on the reactivity and site selectivity of the molecular framework. $E_{\mathrm{HOMO}}$ and $E_{\mathrm{LuMO}}$ clarify the inevitable charge-exchange collaboration inside the studied material, electronegativity $(\chi)$, hardness $(\eta)$, potential $(\mu)$, electrophilicity $(\omega)$ and softness $(\sigma)$ are recorded in Table 4 . The significance of $\eta$ and $\sigma$ is to evaluate both the reactivity and stability. The electron transition from the HOMO to the LUMO energy level is shown in Fig. 8. The HOMO and LUMO are localized in the plane extending over the whole 1benzyl-3-[(1-benzyl-1H-1,2,3-triazol-4-yl)methyl]-2,3-dihydro$1 H$-1,3-benzodiazol-2-one hydrate ring. The energy band gap [ $\left.\Delta E=E_{\mathrm{LUMO}}-E_{\mathrm{HOMO}}\right]$ of the molecule is $5.3468 \mathrm{eV}$, and the frontier molecular orbital energies, $E_{\text {HOMO }}$ and $E_{\mathrm{LUMO}}$ are -6.1633 and $-0.8166 \mathrm{eV}$, respectively.
Table 3

Comparison of selected (X-ray and DFT) geometric data $\left(\AA{ }^{\circ}\right)$.

\begin{tabular}{lll}
\hline Bonds/angles & X-ray & B3LYP/6-311G(d,p) \\
\hline O1-C7 & $1.225(2)$ & 1.25497 \\
N1-C7 & $1.384(2)$ & 1.40076 \\
N1-C6 & $1.397(2)$ & 1.40603 \\
N1-C8 & $1.452(2)$ & 1.46502 \\
N2-C7 & $1.379(2)$ & 1.39180 \\
N2-C1 & $1.395(2)$ & 1.40574 \\
N2-C18 & $1.450(2)$ & 1.47028 \\
N3-N4 & $1.314(2)$ & 1.32954 \\
N3-C10 & $1.358(3)$ & 1.37406 \\
N4-N5 & $1.347(2)$ & 1.38781 \\
N5-C9 & $1.356(2)$ & 1.37548 \\
N5-C11 & 1.47090 \\
C7-N1-C6 & $1.452(2)$ & 109.64541 \\
C7-N1-C8 & $109.72(15)$ & 122.59694 \\
C6-N1-C8 & $123.68(15)$ & 127.83740 \\
C7-N2-C1 & $125.96(15)$ & 109.86320 \\
C7-N2-C18 & $109.90(15)$ & 122.77835 \\
C1-N2-C18 & $123.91(16)$ & 128.23580 \\
N4-N3-C10 & $125.82(16)$ & 108.75382 \\
N3-N4-N5 & $108.55(17)$ & 107.07997 \\
N4-N5-C9 & $107.17(16)$ & 110.25168 \\
N4-N5-C11 & $111.14(15)$ & 118.90455 \\
\hline & $118.44(16)$ & \\
\hline
\end{tabular}

\section{Synthesis and crystallization}

To a mixture of 3-methyl-1-(prop-2-ynyl)-3,4-dihydroquinoxalin- $2(1 \mathrm{H})$-one $(0.65 \mathrm{mmol})$ in ethanol $(20 \mathrm{ml})$ was added 1-(azidomethyl)benzene $(1.04 \mathrm{mmol})$. The mixture was stirred under reflux for $24 \mathrm{~h}$. After completion of the reaction (monitored by TLC), the solution was concentrated and the residue obtained was purified by column chromatography on silica gel by using as eluent a mixture (hexane/ethyl acetate: 9/

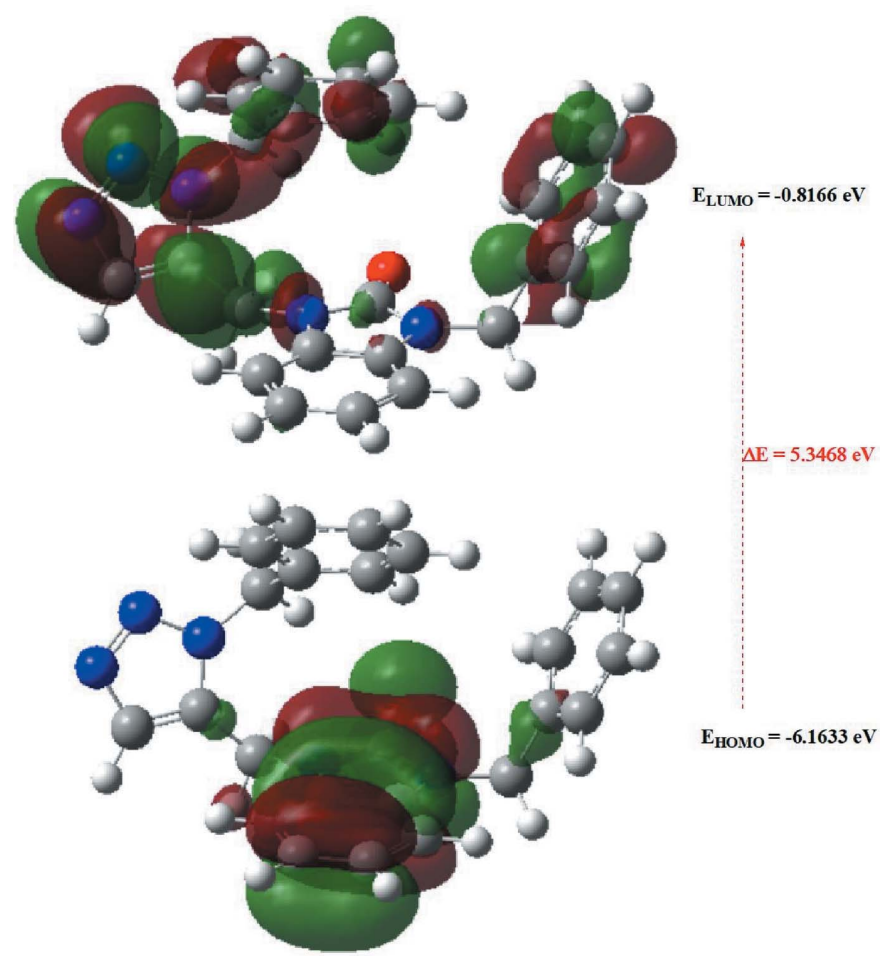

Figure 8

The energy band gap of the title compound, (I). 
Table 4

Calculated energies.

\begin{tabular}{lr}
\hline Molecular Energy (a.u.) (eV) & Compound (I) \\
\hline Total Energy, $T E(\mathrm{eV})$ & -34723.0011 \\
$E_{\text {HOMO }}(\mathrm{eV})$ & -6.1633 \\
$E_{\mathrm{LUMO}}(\mathrm{eV})$ & -0.8166 \\
Gap $\Delta E(\mathrm{eV})$ & 5.3468 \\
Dipole moment, $\mu$ (Debye) & 5.5500 \\
Ionization potential $I(\mathrm{eV})$ & 6.1633 \\
Electron affinity, $A$ & 0.8166 \\
Electronegativity, $\chi$ & 3.4900 \\
Hardness, $\eta$ & 2.6734 \\
Electrophilicity index, $\omega$ & 2.2780 \\
Softness, $\sigma$ & 0.3741 \\
Fraction of electron transferred, $\Delta N$ & 0.6565 \\
\hline
\end{tabular}

1). The isolated solid product was recrystallized from ethanol to afford yellow crystals (yield: in 19\%).

\section{Refinement}

The experimental details including the crystal data, data collection and refinement are summarized in Table 5. Hydrogen atoms were included as riding contributions in idealized positions with $\mathrm{C}-\mathrm{H}=0.95-0.99 \AA$ and $U_{\text {iso }}(\mathrm{H})=$ $1.2 U_{\text {eq }}(\mathrm{C})$.

\section{Funding information}

The support of NSF-MRI grant No. 1228232 for the purchase of the diffractometer and Tulane University for support of the Tulane Crystallography Laboratory are gratefully acknowledged. $\mathrm{TH}$ is grateful to Hacettepe University Scientific Research Project Unit (grant No. 013 D04 602 004).

\section{References}

Ayhan-Kılcıgil, G., Kus, G., Özdamar, E. D., Can-Eke, B. \& Iscan, M. (2007). Arch. Pharm. Chem. Life Sci. 340, 607-611.

Baxter, G. S. \& Clarke, D. E. (1992). Eur. J. Pharmacol. 212, 225-229. Becke, A. D. (1993). J. Chem. Phys. 98, 5648-5652.

Belaziz, D., Kandri Rodi, Y., Essassi, E. M. \& El Ammari, L. (2012). Acta Cryst. E68, o1276.

Belaziz, D., Kandri Rodi, Y., Ouazzani Chahdi, F., Essassi, E. M., Saadi, M. \& El Ammari, L. (2013). Acta Cryst. E69, o122.

Bouayad, K., Kandri Rodi, Y., Ouzidan, Y., Essassi, E. M., Saadi, M. \& El Ammari, L. (2015). Acta Cryst. E71, o735-o736.

Brandenburg, K. \& Putz, H. (2012). DIAMOND. Crystal Impact GbR, Bonn, Germany.

Bruker (2016). APEX3 and SAINT, Bruker AXS, Inc., Madison, Wisconsin, USA.

Díez-Barra, E., Dotor, J., de la Hoz, A., Foces-Foces, C., Enjalbal, C., Aubagnac, J. L., Claramunt, R. M. \& Elguero, J. (1997). Tetrahedron, 53, 7689-7704.

Frisch, M. J., Trucks, G. W., Schlegel, H. B., Scuseria, G. E., Robb, M. A., Cheeseman, J. R., Scalmani, G., Barone, V., Mennucci, B., Petersson, G. A., Nakatsuji, H., Caricato, M., Li, X., Hratchian, H. P., Izmaylov, A. F., Bloino, J., Zheng, G., Sonnenberg, J. L., Hada, M., Ehara, M., Toyota, K., Fukuda, R., Hasegawa, J., Ishida, M., Nakajima, T., Honda, Y., Kitao, O., Nakai, H., Vreven, T., Montgomery, J. A., Jr., Peralta, J. E., Ogliaro, F., Bearpark, M., Heyd, J. J., Brothers, E., Kudin, K. N., Staroverov, V. N., Kobayashi, R., Normand, J., Raghavachari, K., Rendell, A., Burant, J. C., Iyengar, S. S., Tomasi, J., Cossi, M., Rega, N., Millam, J. M., Klene,
Table 5

Experimental details.

\begin{tabular}{ll}
\hline Crystal data & \\
Chemical formula & $\mathrm{C}_{24} \mathrm{H}_{21} \mathrm{~N}_{5} \mathrm{O} \cdot \mathrm{H}_{2} \mathrm{O}$ \\
$M_{\mathrm{r}}$ & 413.47 \\
Crystal system, space group & Monoclinic, $P 2_{1} / c$ \\
Temperature $(\mathrm{K})$ & 150 \\
$a, b, c(\AA)$ & $9.0872(2), 21.1012(4), 11.7134(2)$ \\
$\beta\left({ }^{\circ}\right.$ & $112.654(1)$ \\
$V\left(\AA^{3}\right)$ & $2072.77(7)$ \\
$Z$ & 4 \\
Radiation type & $\mathrm{Cu} K \alpha$ \\
$\mu\left(\mathrm{mm}^{-1}\right)$ & 0.70 \\
Crystal size $(\mathrm{mm})$ & $0.18 \times 0.08 \times 0.01$ \\
& \\
Data collection & Bruker D8 VENTURE PHOTON \\
Diffractometer & $100 \mathrm{CMOS}$ \\
& Multi-scan $(S A D A B S ;$ Krause $e t$ \\
Absorption correction & $a l ., 2015)$ \\
& $0.85,0.99$ \\
$T_{\text {min }}, T_{\text {max }}$ & $15080,3887,2909$ \\
No. of measured, independent and & \\
$\quad$ observed $[I>2 \sigma(I)]$ reflections & 0.057 \\
$R_{\text {int }}$ & 0.610 \\
$(\text { sin } \theta / \lambda)_{\text {max }}\left(\AA^{-1}\right)$ & \\
& \\
Refinement & \\
$R\left[F^{2}>2 \sigma\left(F^{2}\right)\right], w R\left(F^{2}\right), S$ & $0.048,0.113,1.06$ \\
No. of reflections & 3887 \\
No. of parameters & 280 \\
H-atom treatment & $\mathrm{H}$-atom parameters constrained \\
$\Delta \rho_{\text {max }}, \Delta \rho_{\text {min }}\left(\mathrm{e} \AA^{-3}\right)$ & $0.22,-0.22$ \\
\hline &
\end{tabular}

Computer programs: APEX3 and SAINT (Bruker, 2016), SHELXT2014 (Sheldrick, 2015a), SHELXL2018 (Sheldrick, 2015b) and DIAMOND (Brandenburg \& Putz, 2012).

M., Knox, J. E., Cross, J. B., Bakken, V., Adamo, C., Jaramillo, J., Gomperts, R., Stratmann, R. E., Yazyev, O., Austin, A. J., Cammi, R., Pomelli, C., Ochterski, J. W., Martin, R. L., Morokuma, K., Zakrzewski, V. G., Voth, G. A., Salvador, P., Dannenberg, J. J., Dapprich, S., Daniels, A. D., Farkas, ., Foresman, J. B., Ortiz, J. V., Cioslowski, J. \& Fox, D. J. (2009). GAUSSIAN 09. Gaussian Inc., Wallingford, CT, US

Gaba, M., Singh, S. \& Mohan, C. (2014). Eur. J. Med. Chem. 76, 494 505.

Garuti, L., Roberti, M., Malagoli, M., Rossi, T. \& Castelli, M. (2000). Bioorg. Med. Chem. Lett. 10, 2193-2195.

Hathwar, V. R., Sist, M., Jørgensen, M. R. V., Mamakhel, A. H., Wang, X., Hoffmann, C. M., Sugimoto, K., Overgaard, J. \& Iversen, B. B. (2015). IUCrJ, 2, 563-574.

Hirshfeld, F. L. (1977). Theor. Chim. Acta, 44, 129-138.

Krause, L., Herbst-Irmer, R., Sheldrick, G. M. \& Stalke, D. (2015). J. Appl. Cryst. 48, 3-10.

Lakhrissi, B., Benksim, A., Massoui, M., Essassi, el M., Lequart, V., Joly, N., Beaupère, D., Wadouachi, A. \& Martin, P. (2008). Carbohydr. Res. 343, 421-433.

Mavrova, A. Ts, Denkova, P., Tsenov, Y. A., Anichina, K. K. \& Vutchev, D. I. (2007). Bioorg. Med. Chem. 15, 6291-6297.

McKinnon, J. J., Jayatilaka, D. \& Spackman, M. A. (2007). Chem. Commun. pp. 3814-3816.

Mondieig, D., Lakhrissi, L., El Assyry, A., Lakhrissi, B., Negrier, P., Essassi, E. M., Massoui, M., Michel Leger, J. \& Benali, B. (2013). J. Mar. Chim. Heterocycl. 12, 51-61.

Navarrete-Vazquez, G., Cedillo, R., Hernandez-Campos, A., Yepez, L., Hernandez-Luis, F., Valdez, J., Morales, R., Cortes, R., Hernandez, M. \& Castillo, R. (2001). Bioorg Med Chem. 11, 187190.

Olesen, S. P., Munch, E., Moldt, P. \& Drejer, J. (1994). Eur. J. Pharmacol. 251, 53-59. 
Ouzidan, Y., Kandri Rodi, Y., Fronczek, F. R., Venkatraman, R., El Ammari, L. \& Essassi, E. M. (2011). Acta Cryst. E67, o362-o363.

Rao, A., Chimirri, A., De Clercq, E., Monforte, A. M., Monforte, P., Pannecouque, C. \& Zappalà, M. (2002). Farmaco, 57, 819-823.

Ravina, E., Sanchez-Alonso, R., Fueyo, J., Baltar, M. P., Bos, J., Iglesias, R. \& Sanmartin, M. L. (1993). Arzneim. Forsch. 43, 684694.

Rémond, G., Portevin, B., Bonnet, J., Canet, E., Regoli, D. \& De Nanteuil, G. (1997). Eur. J. Med. Chem. 32, 843-868.

Saber, A., Sebbar, N. K., Hökelek, T., El hafi, M., Mague, J. T. \& Essassi, E. M. (2018b). Acta Cryst. E74, 1842-1846.

Saber, A., Sebbar, N. K., Hökelek, T., Hni, B., Mague, J. T. \& Essassi, E. M. (2018a). Acta Cryst. E74, 1746-1750.

Saber, A., Sebbar, N. K., Sert, Y., Alzaqri, N., Hökelek, T., El Ghayati, L., Talbaoui, A., Mague, J. T., Baba, Y. F., Urrutigoîty, M. \& Essassi, M. (2020). J. Mol. Struct. 1200, 127174.
Sebbar, N. K., Mekhzoum, M. E. M., Essassi, E. M., Abdelfettah Z., Ouzidan Y., Kandri, Rodi Y., Talbaoui, A. \& Bakri, Y. (2016). J. Mar. Chim. Heterocycl. 15, 1-11.

Serafin, B., Borkowska, G., Glowczyk, J., Kowalska, I. \& Rump, S. (1989). Pol. J. Pharmcol. Pharm. 41, 89-96.

Sheldrick, G. M. (2015a). Acta Cryst. A71, 3-8.

Sheldrick, G. M. (2015b). Acta Cryst. C71, 3-8.

Spackman, M. A. \& Jayatilaka, D. (2009). CrystEngComm, 11, 19-32.

Thakurdesai, P. A., Wadodkar, S. G. \& Chopade, C. T. (2007). Pharmacology Online 1, 314-329.

Turner, M. J., McKinnon, J. J., Wolff, S. K., Grimwood, D. J., Spackman, P. R., Jayatilaka, D. \& Spackman, M. A. (2017). Crystal Explorer 17. The University of Western Australia.

Venkatesan, P., Thamotharan, S., Ilangovan, A., Liang, H. \& Sundius, T. (2016). Spectrochim. Acta Part A, 153, 625-636. 


\section{supporting information}

Acta Cryst. (2020). E76, 95-101 [https://doi.org/10.1107/S2056989019016876]

Crystal structure, Hirshfeld surface analysis and DFT studies of 1-benzyl-3-[(1benzyl-1H-1,2,3-triazol-5-yl)methyl]-2,3-dihydro-1H-1,3-benzodiazol-2-one monohydrate

Asmaa Saber, Nada Kheira Sebbar, Tuncer Hökelek, Mohamed Labd Taha, Joel T. Mague, Noureddine Hamou Ahabchane and El Mokhtar Essassi

Computing details

Data collection: APEX3 (Bruker, 2016); cell refinement: SAINT (Bruker, 2016); data reduction: SAINT (Bruker, 2016; program(s) used to solve structure: SHELXT2014 (Sheldrick, 2015a); program(s) used to refine structure: SHELXL2018 (Sheldrick, 2015b); molecular graphics: DIAMOND (Brandenburg \& Putz, 2012); software used to prepare material for publication: SHELXL2018 (Sheldrick, 2015b).

1-Benzyl-3-[(1-benzyl-1H-1,2,3-triazol-5-yl)methyl]-2,3-dihydro-1H-1,3-benzodiazol-2-one monohydrate

Crystal data

$\mathrm{C}_{24} \mathrm{H}_{21} \mathrm{~N}_{5} \mathrm{O} \cdot \mathrm{H}_{2} \mathrm{O}$

$M_{r}=413.47$

Monoclinic, $P 2_{1} / c$

$a=9.0872(2) \AA$

$b=21.1012(4) \AA$

$c=11.7134(2) \AA$

$\beta=112.654(1)^{\circ}$

$V=2072.77(7) \AA^{3}$

$Z=4$

Data collection

Bruker D8 VENTURE PHOTON 100 CMOS diffractometer

Radiation source: INCOATEC $\mathrm{I} \mu \mathrm{S}$ micro-focus source

Mirror monochromator

Detector resolution: 10.4167 pixels $\mathrm{mm}^{-1}$

$\omega$ scans

Absorption correction: multi-scan

(SADABS; Krause et al., 2015)

Refinement

Refinement on $F^{2}$

Least-squares matrix: full

$R\left[F^{2}>2 \sigma\left(F^{2}\right)\right]=0.048$

$w R\left(F^{2}\right)=0.113$

$S=1.06$
$F(000)=872$

$D_{\mathrm{x}}=1.325 \mathrm{Mg} \mathrm{m}^{-3}$

$\mathrm{Cu} K \alpha$ radiation, $\lambda=1.54178 \AA$

Cell parameters from 9060 reflections

$\theta=4.2-70.2^{\circ}$

$\mu=0.70 \mathrm{~mm}^{-1}$

$T=150 \mathrm{~K}$

Plate, colourless

$0.18 \times 0.08 \times 0.01 \mathrm{~mm}$

$T_{\min }=0.85, T_{\max }=0.99$

15080 measured reflections

3887 independent reflections

2909 reflections with $I>2 \sigma(I)$

$R_{\text {int }}=0.057$

$\theta_{\max }=70.2^{\circ}, \theta_{\min }=4.2^{\circ}$

$h=-11 \rightarrow 10$

$k=-24 \rightarrow 25$

$l=-14 \rightarrow 13$

3887 reflections

280 parameters

0 restraints

Primary atom site location: structure-invariant direct methods 
Secondary atom site location: difference Fourier map

Hydrogen site location: mixed

$\mathrm{H}$-atom parameters constrained

$$
\begin{aligned}
& w=1 /\left[\sigma^{2}\left(F_{\mathrm{o}}^{2}\right)+(0.0367 P)^{2}+0.901 P\right] \\
& \quad \text { where } P=\left(F_{\mathrm{o}}^{2}+2 F_{\mathrm{c}}^{2}\right) / 3 \\
& (\Delta / \sigma)_{\max }<0.001 \\
& \Delta \rho_{\max }=0.22 \mathrm{e} \AA^{-3} \\
& \Delta \rho_{\min }=-0.21 \mathrm{e} \AA^{-3}
\end{aligned}
$$

\section{Special details}

Geometry. All esds (except the esd in the dihedral angle between two 1.s. planes) are estimated using the full covariance matrix. The cell esds are taken into account individually in the estimation of esds in distances, angles and torsion angles; correlations between esds in cell parameters are only used when they are defined by crystal symmetry. An approximate (isotropic) treatment of cell esds is used for estimating esds involving l.s. planes.

Refinement. Refinement of $\mathrm{F}^{2}$ against ALL reflections. The weighted R-factor $\mathrm{wR}$ and goodness of fit $\mathrm{S}$ are based on $\mathrm{F}^{2}$, conventional R-factors $R$ are based on $F$, with $F$ set to zero for negative $F^{2}$. The threshold expression of $\mathrm{F}^{2}>2 \operatorname{sigma}\left(\mathrm{F}^{2}\right)$ is used only for calculating R-factors(gt) etc. and is not relevant to the choice of reflections for refinement. R-factors based on $\mathrm{F}^{2}$ are statistically about twice as large as those based on F, and R- factors based on ALL data will be even larger. H-

\begin{tabular}{|c|c|c|c|c|}
\hline & $x$ & $y$ & $z$ & $U_{\text {iso }} * / U_{\text {eq }}$ \\
\hline O1 & $0.85567(15)$ & $0.39779(7)$ & $0.93327(13)$ & $0.0375(4)$ \\
\hline N1 & $0.58475(17)$ & $0.39409(7)$ & $0.89638(14)$ & $0.0267(3)$ \\
\hline $\mathrm{N} 2$ & $0.68572(18)$ & $0.48484(7)$ & $0.86568(14)$ & $0.0278(3)$ \\
\hline N3 & $0.3094(2)$ & $0.22818(9)$ & $0.68794(17)$ & $0.0426(5)$ \\
\hline N4 & $0.4467(2)$ & $0.21861(8)$ & $0.67770(16)$ & $0.0378(4)$ \\
\hline N5 & 0.55663 (19) & $0.25352(8)$ & $0.76599(15)$ & $0.0300(4)$ \\
\hline $\mathrm{C} 1$ & $0.5258(2)$ & $0.49606(9)$ & $0.84381(16)$ & $0.0274(4)$ \\
\hline $\mathrm{C} 2$ & $0.4364(2)$ & $0.55101(10)$ & $0.81370(18)$ & $0.0350(5)$ \\
\hline $\mathrm{H} 2$ & 0.480398 & 0.590041 & 0.801540 & $0.042 *$ \\
\hline $\mathrm{C} 3$ & 0.2785 & $0.54622(11)$ & $0.80211(19)$ & $0.0411(5)$ \\
\hline $\mathrm{H} 3$ & 0.213195 & 0.583008 & 0.781973 & $0.049 *$ \\
\hline $\mathrm{C} 4$ & $0.2141(2)$ & $0.48927(12)$ & $0.8192(2)$ & $0.0416(5)$ \\
\hline $\mathrm{H} 4$ & 0.105243 & 0.487817 & 0.808961 & $0.050 *$ \\
\hline $\mathrm{C} 5$ & $0.3051(2)$ & $0.43389(11)$ & $0.85099(18)$ & $0.0342(5)$ \\
\hline H5 & 0.261424 & 0.394902 & 0.863712 & $0.041 *$ \\
\hline C6 & $0.4618(2)$ & $0.43874(9)$ & $0.86300(16)$ & $0.0263(4)$ \\
\hline $\mathrm{C} 7$ & $0.7242(2)$ & $0.42276(9)$ & $0.90173(17)$ & $0.0275(4)$ \\
\hline $\mathrm{C} 8$ & $0.5772(2)$ & $0.32986(9)$ & $0.93828(18)$ & 0.0307 (4) \\
\hline H8A & 0.523147 & 0.330364 & 0.997257 & $0.037^{*}$ \\
\hline H8B & 0.686995 & 0.313896 & 0.982830 & $0.037^{*}$ \\
\hline C9 & $0.4903(2)$ & $0.28571(9)$ & $0.83436(17)$ & $0.0288(4)$ \\
\hline $\mathrm{C} 10$ & $0.3330(2)$ & $0.26854(10)$ & $0.7837(2)$ & $0.0381(5)$ \\
\hline H10 & 0.252957 & 0.282630 & 0.811211 & $0.046^{*}$ \\
\hline C11 & $0.7188(2)$ & $0.25400(10)$ & $0.77111(19)$ & $0.0337(5)$ \\
\hline H11A & 0.752881 & 0.209810 & 0.766704 & $0.040 *$ \\
\hline H11B & 0.790188 & 0.271831 & 0.851613 & $0.040^{*}$ \\
\hline $\mathrm{C} 12$ & $0.7378(2)$ & $0.29187(9)$ & $0.66852(17)$ & $0.0303(4)$ \\
\hline $\mathrm{C} 13$ & $0.6180(3)$ & $0.32884(10)$ & 0.58683 (19) & $0.0372(5)$ \\
\hline
\end{tabular}
atoms attached to carbon were placed in calculated positions $(\mathrm{C}-\mathrm{H}=0.95-0.99 \AA)$ while those attached to oxygen were placed in locations derived from a difference map and their coordinates adjusted to give $\mathrm{O}-\mathrm{H}=0.87 \AA$. All were included as riding contributions with isotropic displacement parameters $1.2-1.5$ times those of the attached atoms.

Fractional atomic coordinates and isotropic or equivalent isotropic displacement parameters $\left(\hat{A}^{2}\right)$ 


$\begin{array}{lllll}\text { H13 } & 0.516342 & 0.330255 & 0.592204 & 0.045^{*} \\ \text { C14 } & 0.6458(3) & 0.36398(11) & 0.4968(2) & 0.0439(5) \\ \text { H14 } & 0.562951 & 0.389101 & 0.440157 & 0.053^{*} \\ \text { C15 } & 0.7931(3) & 0.36233(12) & 0.4897(2) & 0.0499(6) \\ \text { H15 } & 0.813571 & 0.387548 & 0.430265 & 0.060^{*} \\ \text { C16 } & 0.9119(3) & 0.32390(14) & 0.5694(2) & 0.0531(7) \\ \text { H16 } & 1.012885 & 0.321923 & 0.563017 & 0.064^{*} \\ \text { C17 } & 0.8840(3) & 0.28853(12) & 0.6578(2) & 0.0439(6) \\ \text { H17 } & 0.965324 & 0.261779 & 0.711555 & 0.053^{*} \\ \text { C18 } & 0.8011(2) & 0.53227(10) & 0.86554(18) & 0.0336(5) \\ \text { H18A } & 0.909556 & 0.515338 & 0.911413 & 0.040^{*} \\ \text { H18B } & 0.787800 & 0.570113 & 0.910627 & 0.040^{*} \\ \text { C19 } & 0.7883(2) & 0.55247(9) & 0.73841(17) & 0.0280(4) \\ \text { C20 } & 0.7223(3) & 0.51411(11) & 0.6354(2) & 0.0435(5) \\ \text { H20 } & 0.679963 & 0.473924 & 0.643246 & 0.052^{*} \\ \text { C21 } & 0.7171(3) & 0.53360(12) & 0.5208(2) & 0.0493(6) \\ \text { H21 } & 0.671787 & 0.506684 & 0.450937 & 0.059^{*} \\ \text { C22 } & 0.7773(3) & 0.59167(12) & 0.5081(2) & 0.0430(5) \\ \text { H22 } & 0.772714 & 0.605182 & 0.429394 & 0.052^{*} \\ \text { C23 } & 0.8446(3) & 0.63033(11) & 0.6103(2) & 0.0432(5) \\ \text { H23 } & 0.886487 & 0.670536 & 0.602007 & 0.052^{*} \\ \text { C24 } & 0.8509(2) & 0.61052(10) & 0.7246(2) & 0.0357(5) \\ \text { H24 } & 0.898875 & 0.637078 & 0.794666 & 0.043^{*} \\ \text { O2 } & 0.10404(17) & 0.18802(8) & 0.44186(14) & 0.0478(4) \\ \text { H2A } & 0.155922 & 0.195519 & 0.520249 & 0.072^{*} \\ \text { H2B } & 0.031707 & 0.160858 & 0.441258 & 0.072^{*} \\ & & & & \end{array}$

Atomic displacement parameters $\left(\AA^{2}\right)$

\begin{tabular}{lllllll}
\hline & $U^{11}$ & $U^{22}$ & $U^{33}$ & $U^{12}$ & $U^{13}$ & $U^{23}$ \\
\hline O1 & $0.0242(7)$ & $0.0395(9)$ & $0.0441(8)$ & $0.0055(6)$ & $0.0078(6)$ & $-0.0002(7)$ \\
$\mathrm{N} 1$ & $0.0247(8)$ & $0.0244(8)$ & $0.0286(8)$ & $0.0013(6)$ & $0.0077(6)$ & $-0.0006(6)$ \\
$\mathrm{N} 2$ & $0.0259(8)$ & $0.0263(9)$ & $0.0283(8)$ & $-0.0016(7)$ & $0.0072(6)$ & $0.0013(7)$ \\
$\mathrm{N} 3$ & $0.0363(9)$ & $0.0486(12)$ & $0.0454(11)$ & $-0.0144(9)$ & $0.0184(8)$ & $-0.0126(9)$ \\
$\mathrm{N} 4$ & $0.0385(9)$ & $0.0358(10)$ & $0.0409(10)$ & $-0.0099(8)$ & $0.0174(8)$ & $-0.0081(8)$ \\
$\mathrm{N} 5$ & $0.0306(8)$ & $0.0291(9)$ & $0.0316(9)$ & $-0.0037(7)$ & $0.0132(7)$ & $-0.0018(7)$ \\
C1 & $0.0267(9)$ & $0.0319(11)$ & $0.0206(9)$ & $0.0029(8)$ & $0.0059(7)$ & $-0.0007(7)$ \\
C2 & $0.0430(11)$ & $0.0328(12)$ & $0.0277(10)$ & $0.0085(9)$ & $0.0120(9)$ & $0.0036(8)$ \\
C3 & $0.0438(12)$ & $0.0442(14)$ & $0.0339(11)$ & $0.0195(10)$ & $0.0134(9)$ & $0.0054(9)$ \\
C4 & $0.0303(10)$ & $0.0591(15)$ & $0.0360(12)$ & $0.0118(10)$ & $0.0132(9)$ & $0.0009(10)$ \\
C5 & $0.0302(10)$ & $0.0429(13)$ & $0.0311(10)$ & $0.0015(9)$ & $0.0135(8)$ & $-0.0007(9)$ \\
C6 & $0.0255(9)$ & $0.0303(11)$ & $0.0215(9)$ & $0.0024(8)$ & $0.0071(7)$ & $-0.0011(8)$ \\
C7 & $0.0232(9)$ & $0.0302(10)$ & $0.0252(9)$ & $-0.0006(8)$ & $0.0050(7)$ & $-0.0023(8)$ \\
C8 & $0.0345(10)$ & $0.0279(11)$ & $0.0280(10)$ & $0.0011(8)$ & $0.0101(8)$ & $0.0026(8)$ \\
C9 & $0.0309(9)$ & $0.0272(10)$ & $0.0297(10)$ & $-0.0018(8)$ & $0.0132(8)$ & $0.0019(8)$ \\
C10 & $0.0350(11)$ & $0.0409(13)$ & $0.0416(12)$ & $-0.0073(9)$ & $0.0182(9)$ & $-0.0083(10)$ \\
C11 & $0.0288(10)$ & $0.0375(12)$ & $0.0362(11)$ & $0.0025(9)$ & $0.0138(8)$ & $0.0018(9)$ \\
C12 & $0.0303(10)$ & $0.0318(11)$ & $0.0283(10)$ & $-0.0052(8)$ & $0.0108(8)$ & $-0.0047(8)$
\end{tabular}




\begin{tabular}{lllllll} 
C13 & $0.0401(11)$ & $0.0333(12)$ & $0.0401(12)$ & $0.0026(9)$ & $0.0177(9)$ & $0.0022(9)$ \\
C14 & $0.0584(14)$ & $0.0363(13)$ & $0.0350(12)$ & $0.0035(11)$ & $0.0159(10)$ & $0.0016(9)$ \\
C15 & $0.0679(16)$ & $0.0510(15)$ & $0.0377(13)$ & $-0.0150(13)$ & $0.0279(12)$ & $-0.0003(11)$ \\
C16 & $0.0404(12)$ & $0.0785(19)$ & $0.0447(14)$ & $-0.0136(13)$ & $0.0211(11)$ & $0.0002(13)$ \\
C17 & $0.0313(10)$ & $0.0601(16)$ & $0.0386(12)$ & $-0.0021(10)$ & $0.0115(9)$ & $0.0025(11)$ \\
C18 & $0.0328(10)$ & $0.0340(11)$ & $0.0296(10)$ & $-0.0092(9)$ & $0.0070(8)$ & $-0.0023(9)$ \\
C19 & $0.0240(9)$ & $0.0285(10)$ & $0.0309(10)$ & $-0.0005(8)$ & $0.0099(7)$ & $-0.0008(8)$ \\
C20 & $0.0551(14)$ & $0.0388(13)$ & $0.0352(12)$ & $-0.0153(11)$ & $0.0159(10)$ & $-0.0061(10)$ \\
C21 & $0.0625(15)$ & $0.0503(15)$ & $0.0340(12)$ & $-0.0167(12)$ & $0.0173(11)$ & $-0.0101(11)$ \\
C22 & $0.0454(12)$ & $0.0512(15)$ & $0.0351(12)$ & $-0.0047(11)$ & $0.0188(10)$ & $0.0023(10)$ \\
C23 & $0.0494(13)$ & $0.0384(13)$ & $0.0491(13)$ & $-0.0075(10)$ & $0.0272(11)$ & $0.0008(10)$ \\
C24 & $0.0376(11)$ & $0.0323(11)$ & $0.0393(12)$ & $-0.0052(9)$ & $0.0171(9)$ & $-0.0062(9)$ \\
O2 & $0.0397(8)$ & $0.0618(11)$ & $0.0395(9)$ & $-0.0154(8)$ & $0.0128(7)$ & $0.0018(8)$ \\
\hline
\end{tabular}

Geometric parameters $\left(\AA,{ }^{\circ}\right)$

\begin{tabular}{|c|c|c|c|}
\hline $\mathrm{O} 1-\mathrm{C} 7$ & $1.225(2)$ & C11-H11B & 0.9900 \\
\hline $\mathrm{N} 1-\mathrm{C} 7$ & $1.384(2)$ & $\mathrm{C} 12-\mathrm{C} 13$ & $1.381(3)$ \\
\hline $\mathrm{N} 1-\mathrm{C} 6$ & $1.397(2)$ & $\mathrm{C} 12-\mathrm{C} 17$ & $1.384(3)$ \\
\hline $\mathrm{N} 1-\mathrm{C} 8$ & $1.452(2)$ & $\mathrm{C} 13-\mathrm{C} 14$ & $1.390(3)$ \\
\hline $\mathrm{N} 2-\mathrm{C} 7$ & $1.379(2)$ & $\mathrm{C} 13-\mathrm{H} 13$ & 0.9500 \\
\hline $\mathrm{N} 2-\mathrm{C} 1$ & $1.395(2)$ & $\mathrm{C} 14-\mathrm{C} 15$ & $1.373(3)$ \\
\hline $\mathrm{N} 2-\mathrm{C} 18$ & $1.450(2)$ & $\mathrm{C} 14-\mathrm{H} 14$ & 0.9500 \\
\hline $\mathrm{N} 3-\mathrm{N} 4$ & $1.314(2)$ & $\mathrm{C} 15-\mathrm{C} 16$ & $1.385(4)$ \\
\hline $\mathrm{N} 3-\mathrm{C} 10$ & $1.358(3)$ & C15-H15 & 0.9500 \\
\hline $\mathrm{N} 4-\mathrm{N} 5$ & $1.347(2)$ & $\mathrm{C} 16-\mathrm{C} 17$ & $1.377(3)$ \\
\hline N5-C9 & $1.356(2)$ & $\mathrm{C} 16-\mathrm{H} 16$ & 0.9500 \\
\hline N5-C11 & $1.452(2)$ & C17-H17 & 0.9500 \\
\hline $\mathrm{C} 1-\mathrm{C} 2$ & $1.381(3)$ & $\mathrm{C} 18-\mathrm{C} 19$ & $1.510(3)$ \\
\hline $\mathrm{C} 1-\mathrm{C} 6$ & $1.397(3)$ & $\mathrm{C} 18-\mathrm{H} 18 \mathrm{~A}$ & 0.9900 \\
\hline $\mathrm{C} 2-\mathrm{C} 3$ & $1.392(3)$ & C18- $1818 B$ & 0.9900 \\
\hline $\mathrm{C} 2-\mathrm{H} 2$ & 0.9500 & $\mathrm{C} 19-\mathrm{C} 20$ & $1.383(3)$ \\
\hline $\mathrm{C} 3-\mathrm{C} 4$ & $1.384(3)$ & $\mathrm{C} 19-\mathrm{C} 24$ & $1.386(3)$ \\
\hline $\mathrm{C} 3-\mathrm{H} 3$ & 0.9500 & $\mathrm{C} 20-\mathrm{C} 21$ & $1.387(3)$ \\
\hline $\mathrm{C} 4-\mathrm{C} 5$ & $1.397(3)$ & $\mathrm{C} 20-\mathrm{H} 20$ & 0.9500 \\
\hline $\mathrm{C} 4-\mathrm{H} 4$ & 0.9500 & $\mathrm{C} 21-\mathrm{C} 22$ & $1.373(3)$ \\
\hline $\mathrm{C} 5-\mathrm{C} 6$ & $1.379(3)$ & $\mathrm{C} 21-\mathrm{H} 21$ & 0.9500 \\
\hline $\mathrm{C} 5-\mathrm{H} 5$ & 0.9500 & $\mathrm{C} 22-\mathrm{C} 23$ & $1.382(3)$ \\
\hline $\mathrm{C} 8-\mathrm{C} 9$ & $1.494(3)$ & $\mathrm{C} 22-\mathrm{H} 22$ & 0.9500 \\
\hline $\mathrm{C} 8-\mathrm{H} 8 \mathrm{~A}$ & 0.9900 & $\mathrm{C} 23-\mathrm{C} 24$ & $1.383(3)$ \\
\hline C $8-\mathrm{H} 8 \mathrm{~B}$ & 0.9900 & $\mathrm{C} 23-\mathrm{H} 23$ & 0.9500 \\
\hline $\mathrm{C} 9-\mathrm{C} 10$ & $1.368(3)$ & $\mathrm{C} 24-\mathrm{H} 24$ & 0.9500 \\
\hline $\mathrm{C} 10-\mathrm{H} 10$ & 0.9500 & $\mathrm{O} 2-\mathrm{H} 2 \mathrm{~A}$ & 0.8700 \\
\hline $\mathrm{C} 11-\mathrm{C} 12$ & $1.507(3)$ & $\mathrm{O} 2-\mathrm{H} 2 \mathrm{~B}$ & 0.8701 \\
\hline $\mathrm{C} 11-\mathrm{H} 11 \mathrm{~A}$ & 0.9900 & & \\
\hline $\mathrm{O} 2 \cdots \mathrm{O} 1^{\mathrm{i}}$ & $2.865(2)$ & $\mathrm{C} 10 \cdots \mathrm{H} 5$ & 2.98 \\
\hline $\mathrm{O} 2 \cdots \mathrm{C} 17^{\mathrm{i}}$ & $3.192(3)$ & $\mathrm{C} 11 \cdots \mathrm{H} 8 \mathrm{~B}$ & 2.90 \\
\hline
\end{tabular}




\begin{tabular}{|c|c|c|c|}
\hline $\mathrm{O} 2 \cdots \mathrm{N} 3$ & $2.892(2)$ & $\mathrm{C} 14 \cdots \mathrm{H} 20$ & 2.83 \\
\hline 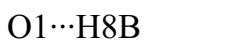 & 2.55 & $\mathrm{C} 18 \cdots \mathrm{H} 2$ & 2.98 \\
\hline $\mathrm{O} 1 \cdots \mathrm{H} 11 \mathrm{~B}$ & 2.81 & $\mathrm{C} 22 \cdots \mathrm{H} 16^{\mathrm{vii}}$ & 2.98 \\
\hline $\mathrm{O} 1 \cdots \mathrm{H} 18 \mathrm{~A}$ & 2.56 & $\mathrm{C} 22 \cdots \mathrm{H} 13^{\mathrm{vi}}$ & 2.97 \\
\hline $\mathrm{O} 1 \cdots \mathrm{H} 18 \mathrm{~A}^{\mathrm{ii}}$ & 2.87 & $\mathrm{C} 23 \cdots \mathrm{H} 16^{\mathrm{vii}}$ & 2.97 \\
\hline $\mathrm{O} 2 \cdots \mathrm{H} 5^{\mathrm{iii}}$ & 2.64 & $\mathrm{H} 2 \cdots \mathrm{N} 44^{\text {viii }}$ & 2.78 \\
\hline $\mathrm{O} 2 \cdots \mathrm{H} 11 \mathrm{~B}^{\mathrm{i}}$ & 2.77 & $\mathrm{H} 2 \mathrm{~A} \cdots \mathrm{N} 4$ & 2.62 \\
\hline $\mathrm{O} 2 \cdots \mathrm{H} 17^{\mathrm{i}}$ & 2.71 & $\mathrm{H} 2 \mathrm{~A} \cdots \mathrm{N} 3$ & 2.04 \\
\hline $\mathrm{N} 4 \cdots \mathrm{C} 13$ & $3.200(3)$ & $\mathrm{H} 2 \mathrm{~B} \cdots \mathrm{O} 1^{\mathrm{i}}$ & 2.00 \\
\hline $\mathrm{N} 2 \cdots \mathrm{H} 20$ & 2.60 & $\mathrm{H} 2 \mathrm{~B} \cdots \mathrm{H} 11 \mathrm{~B}^{\mathrm{i}}$ & 2.48 \\
\hline $\mathrm{N} 4 \cdots \mathrm{H} 13$ & 2.73 & $\mathrm{H} 3 \cdots \mathrm{H} 15^{\mathrm{vi}}$ & 2.48 \\
\hline $\mathrm{N} 5 \cdots \mathrm{H} 13$ & 2.52 & $\mathrm{H} 4 \cdots H 18 \mathrm{~A}^{\mathrm{ix}}$ & 2.57 \\
\hline $\mathrm{C} 1 \cdots \mathrm{C} 20$ & $3.557(3)$ & $\mathrm{H} 5 \cdots \mathrm{H} 10$ & 2.44 \\
\hline $\mathrm{C} 2 \cdots \mathrm{C}^{\text {iv }}$ & $3.542(3)$ & $\mathrm{H} 8 \mathrm{~A} \cdots \mathrm{N} 4^{\mathrm{v}}$ & 2.67 \\
\hline $\mathrm{C} 3 \cdots \mathrm{C} 7^{\mathrm{iv}}$ & $3.540(3)$ & H8B $\cdots H 11 B$ & 2.27 \\
\hline $\mathrm{C} 5 \cdots \mathrm{C} 9$ & $3.592(3)$ & $\mathrm{H} 10 \cdots \mathrm{O} 2^{v}$ & 2.48 \\
\hline $\mathrm{C} 9 \cdots \mathrm{C} 5$ & $3.592(3)$ & $\mathrm{H} 10 \cdots \mathrm{H} 17^{\text {ix }}$ & 2.46 \\
\hline $\mathrm{C} 10 \cdots \mathrm{O} 2^{v}$ & $3.402(3)$ & $\mathrm{H} 11 \mathrm{~A} \cdots \mathrm{C} 15^{\mathrm{v}}$ & 2.92 \\
\hline $\mathrm{C} 11 \cdots \mathrm{C} 15^{\mathrm{v}}$ & $3.421(3)$ & $\mathrm{H} 11 \mathrm{~A} \cdots \mathrm{H} 17$ & 2.51 \\
\hline $\mathrm{C} 14 \cdots \mathrm{C} 20$ & $3.505(3)$ & $\mathrm{H} 16 \cdots \mathrm{H} 23^{\mathrm{vii}}$ & 2.44 \\
\hline $\mathrm{C} 2 \cdots \mathrm{H} 18 \mathrm{~B}$ & 2.98 & $\mathrm{H} 16 \cdots \mathrm{H} 22^{\mathrm{vii}}$ & 2.46 \\
\hline $\mathrm{C} 3 \cdots \mathrm{H} 15^{\mathrm{vi}}$ & 2.88 & $\mathrm{H} 18 \mathrm{~A} \cdots \mathrm{H} 18 \mathrm{~A}^{\mathrm{ii}}$ & 2.19 \\
\hline $\mathrm{C} 8 \cdots \mathrm{H} 11 \mathrm{~B}$ & 2.79 & $\mathrm{H} 18 \mathrm{~B} \cdots \mathrm{H} 24$ & 2.43 \\
\hline $\mathrm{C} 8 \cdots \mathrm{H} 5$ & 2.99 & $\mathrm{H} 24 \cdots \mathrm{N} 3^{\text {viii }}$ & 2.76 \\
\hline $\mathrm{C} 7-\mathrm{N} 1-\mathrm{C} 6$ & $109.72(15)$ & $\mathrm{N} 5-\mathrm{C} 11-\mathrm{H} 11 \mathrm{~B}$ & 108.9 \\
\hline $\mathrm{C} 7-\mathrm{N} 1-\mathrm{C} 8$ & $123.68(15)$ & $\mathrm{C} 12-\mathrm{C} 11-\mathrm{H} 11 \mathrm{~B}$ & 108.9 \\
\hline $\mathrm{C} 6-\mathrm{N} 1-\mathrm{C} 8$ & $125.96(15)$ & $\mathrm{H} 11 \mathrm{~A}-\mathrm{C} 11-\mathrm{H} 11 \mathrm{~B}$ & 107.7 \\
\hline $\mathrm{C} 7-\mathrm{N} 2-\mathrm{C} 1$ & $109.90(15)$ & $\mathrm{C} 13-\mathrm{C} 12-\mathrm{C} 17$ & $119.63(19)$ \\
\hline $\mathrm{C} 7-\mathrm{N} 2-\mathrm{C} 18$ & $123.91(16)$ & $\mathrm{C} 13-\mathrm{C} 12-\mathrm{C} 11$ & $123.39(18)$ \\
\hline $\mathrm{C} 1-\mathrm{N} 2-\mathrm{C} 18$ & $125.82(16)$ & $\mathrm{C} 17-\mathrm{C} 12-\mathrm{C} 11$ & $116.99(18)$ \\
\hline $\mathrm{N} 4-\mathrm{N} 3-\mathrm{C} 10$ & $108.55(17)$ & $\mathrm{C} 12-\mathrm{C} 13-\mathrm{C} 14$ & $120.1(2)$ \\
\hline $\mathrm{N} 3-\mathrm{N} 4-\mathrm{N} 5$ & $107.17(16)$ & $\mathrm{C} 12-\mathrm{C} 13-\mathrm{H} 13$ & 119.9 \\
\hline $\mathrm{N} 4-\mathrm{N} 5-\mathrm{C} 9$ & $111.14(15)$ & $\mathrm{C} 14-\mathrm{C} 13-\mathrm{H} 13$ & 119.9 \\
\hline $\mathrm{N} 4-\mathrm{N} 5-\mathrm{C} 11$ & $118.44(16)$ & $\mathrm{C} 15-\mathrm{C} 14-\mathrm{C} 13$ & $119.9(2)$ \\
\hline $\mathrm{C} 9-\mathrm{N} 5-\mathrm{C} 11$ & $130.35(17)$ & $\mathrm{C} 15-\mathrm{C} 14-\mathrm{H} 14$ & 120.1 \\
\hline $\mathrm{C} 2-\mathrm{C} 1-\mathrm{N} 2$ & $131.12(19)$ & $\mathrm{C} 13-\mathrm{C} 14-\mathrm{H} 14$ & 120.1 \\
\hline $\mathrm{C} 2-\mathrm{C} 1-\mathrm{C} 6$ & $121.84(18)$ & $\mathrm{C} 14-\mathrm{C} 15-\mathrm{C} 16$ & $120.0(2)$ \\
\hline $\mathrm{N} 2-\mathrm{C} 1-\mathrm{C} 6$ & $106.99(16)$ & $\mathrm{C} 14-\mathrm{C} 15-\mathrm{H} 15$ & 120.0 \\
\hline $\mathrm{C} 1-\mathrm{C} 2-\mathrm{C} 3$ & $116.5(2)$ & $\mathrm{C} 16-\mathrm{C} 15-\mathrm{H} 15$ & 120.0 \\
\hline $\mathrm{C} 1-\mathrm{C} 2-\mathrm{H} 2$ & 121.7 & $\mathrm{C} 17-\mathrm{C} 16-\mathrm{C} 15$ & $120.2(2)$ \\
\hline $\mathrm{C} 3-\mathrm{C} 2-\mathrm{H} 2$ & 121.7 & $\mathrm{C} 17-\mathrm{C} 16-\mathrm{H} 16$ & 119.9 \\
\hline $\mathrm{C} 4-\mathrm{C} 3-\mathrm{C} 2$ & $121.7(2)$ & $\mathrm{C} 15-\mathrm{C} 16-\mathrm{H} 16$ & 119.9 \\
\hline $\mathrm{C} 4-\mathrm{C} 3-\mathrm{H} 3$ & 119.1 & $\mathrm{C} 16-\mathrm{C} 17-\mathrm{C} 12$ & $120.1(2)$ \\
\hline $\mathrm{C} 2-\mathrm{C} 3-\mathrm{H} 3$ & 119.1 & $\mathrm{C} 16-\mathrm{C} 17-\mathrm{H} 17$ & 119.9 \\
\hline $\mathrm{C} 3-\mathrm{C} 4-\mathrm{C} 5$ & $121.65(19)$ & $\mathrm{C} 12-\mathrm{C} 17-\mathrm{H} 17$ & 119.9 \\
\hline $\mathrm{C} 3-\mathrm{C} 4-\mathrm{H} 4$ & 119.2 & $\mathrm{~N} 2-\mathrm{C} 18-\mathrm{C} 19$ & $114.52(15)$ \\
\hline $\mathrm{C} 5-\mathrm{C} 4-\mathrm{H} 4$ & 119.2 & $\mathrm{~N} 2-\mathrm{C} 18-\mathrm{H} 18 \mathrm{~A}$ & 108.6 \\
\hline
\end{tabular}




\begin{tabular}{|c|c|c|c|}
\hline $\mathrm{C} 6-\mathrm{C} 5-\mathrm{C} 4$ & $116.6(2)$ & $\mathrm{C} 19-\mathrm{C} 18-\mathrm{H} 18 \mathrm{~A}$ & 108.6 \\
\hline $\mathrm{C} 6-\mathrm{C} 5-\mathrm{H} 5$ & 121.7 & $\mathrm{~N} 2-\mathrm{C} 18-\mathrm{H} 18 \mathrm{~B}$ & 108.6 \\
\hline $\mathrm{C} 4-\mathrm{C} 5-\mathrm{H} 5$ & 121.7 & $\mathrm{C} 19-\mathrm{C} 18-\mathrm{H} 18 \mathrm{~B}$ & 108.6 \\
\hline $\mathrm{C} 5-\mathrm{C} 6-\mathrm{C} 1$ & $121.66(18)$ & $\mathrm{H} 18 \mathrm{~A}-\mathrm{C} 18-\mathrm{H} 18 \mathrm{~B}$ & 107.6 \\
\hline $\mathrm{C} 5-\mathrm{C} 6-\mathrm{N} 1$ & $131.39(18)$ & $\mathrm{C} 20-\mathrm{C} 19-\mathrm{C} 24$ & $118.34(19)$ \\
\hline $\mathrm{C} 1-\mathrm{C} 6-\mathrm{N} 1$ & $106.93(15)$ & $\mathrm{C} 20-\mathrm{C} 19-\mathrm{C} 18$ & $122.54(18)$ \\
\hline $\mathrm{O} 1-\mathrm{C} 7-\mathrm{N} 2$ & $127.11(18)$ & $\mathrm{C} 24-\mathrm{C} 19-\mathrm{C} 18$ & $119.06(17)$ \\
\hline $\mathrm{O} 1-\mathrm{C} 7-\mathrm{N} 1$ & $126.52(18)$ & $\mathrm{C} 19-\mathrm{C} 20-\mathrm{C} 21$ & $120.8(2)$ \\
\hline $\mathrm{N} 2-\mathrm{C} 7-\mathrm{N} 1$ & $106.37(15)$ & $\mathrm{C} 19-\mathrm{C} 20-\mathrm{H} 20$ & 119.6 \\
\hline $\mathrm{N} 1-\mathrm{C} 8-\mathrm{C} 9$ & $112.68(15)$ & $\mathrm{C} 21-\mathrm{C} 20-\mathrm{H} 20$ & 119.6 \\
\hline $\mathrm{N} 1-\mathrm{C} 8-\mathrm{H} 8 \mathrm{~A}$ & 109.1 & $\mathrm{C} 22-\mathrm{C} 21-\mathrm{C} 20$ & $120.2(2)$ \\
\hline $\mathrm{C} 9-\mathrm{C} 8-\mathrm{H} 8 \mathrm{~A}$ & 109.1 & $\mathrm{C} 22-\mathrm{C} 21-\mathrm{H} 21$ & 119.9 \\
\hline $\mathrm{N} 1-\mathrm{C} 8-\mathrm{H} 8 \mathrm{~B}$ & 109.1 & $\mathrm{C} 20-\mathrm{C} 21-\mathrm{H} 21$ & 119.9 \\
\hline $\mathrm{C} 9-\mathrm{C} 8-\mathrm{H} 8 \mathrm{~B}$ & 109.1 & $\mathrm{C} 21-\mathrm{C} 22-\mathrm{C} 23$ & $119.6(2)$ \\
\hline $\mathrm{H} 8 \mathrm{~A}-\mathrm{C} 8-\mathrm{H} 8 \mathrm{~B}$ & 107.8 & $\mathrm{C} 21-\mathrm{C} 22-\mathrm{H} 22$ & 120.2 \\
\hline $\mathrm{N} 5-\mathrm{C} 9-\mathrm{C} 10$ & $103.82(17)$ & $\mathrm{C} 23-\mathrm{C} 22-\mathrm{H} 22$ & 120.2 \\
\hline $\mathrm{N} 5-\mathrm{C} 9-\mathrm{C} 8$ & $125.29(17)$ & $\mathrm{C} 22-\mathrm{C} 23-\mathrm{C} 24$ & $120.0(2)$ \\
\hline $\mathrm{C} 10-\mathrm{C} 9-\mathrm{C} 8$ & $130.88(18)$ & $\mathrm{C} 22-\mathrm{C} 23-\mathrm{H} 23$ & 120.0 \\
\hline $\mathrm{N} 3-\mathrm{C} 10-\mathrm{C} 9$ & $109.31(18)$ & $\mathrm{C} 24-\mathrm{C} 23-\mathrm{H} 23$ & 120.0 \\
\hline $\mathrm{N} 3-\mathrm{C} 10-\mathrm{H} 10$ & 125.3 & $\mathrm{C} 23-\mathrm{C} 24-\mathrm{C} 19$ & $121.0(2)$ \\
\hline $\mathrm{C} 9-\mathrm{C} 10-\mathrm{H} 10$ & 125.3 & $\mathrm{C} 23-\mathrm{C} 24-\mathrm{H} 24$ & 119.5 \\
\hline $\mathrm{N} 5-\mathrm{C} 11-\mathrm{C} 12$ & $113.37(16)$ & $\mathrm{C} 19-\mathrm{C} 24-\mathrm{H} 24$ & 119.5 \\
\hline $\mathrm{N} 5-\mathrm{C} 11-\mathrm{H} 11 \mathrm{~A}$ & 108.9 & $\mathrm{H} 2 \mathrm{~A}-\mathrm{O} 2-\mathrm{H} 2 \mathrm{~B}$ & 103.2 \\
\hline $\mathrm{C} 12-\mathrm{C} 11-\mathrm{H} 11 \mathrm{~A}$ & 108.9 & & \\
\hline $\mathrm{C} 10-\mathrm{N} 3-\mathrm{N} 4-\mathrm{N} 5$ & $-0.7(2)$ & $\mathrm{C} 11-\mathrm{N} 5-\mathrm{C} 9-\mathrm{C} 10$ & $177.1(2)$ \\
\hline $\mathrm{N} 3-\mathrm{N} 4-\mathrm{N} 5-\mathrm{C} 9$ & $0.3(2)$ & $\mathrm{N} 4-\mathrm{N} 5-\mathrm{C} 9-\mathrm{C} 8$ & $-178.77(17)$ \\
\hline $\mathrm{N} 3-\mathrm{N} 4-\mathrm{N} 5-\mathrm{C} 11$ & $-176.95(17)$ & $\mathrm{C} 11-\mathrm{N} 5-\mathrm{C} 9-\mathrm{C} 8$ & $-1.9(3)$ \\
\hline $\mathrm{C} 7-\mathrm{N} 2-\mathrm{C} 1-\mathrm{C} 2$ & $175.59(19)$ & $\mathrm{N} 1-\mathrm{C} 8-\mathrm{C} 9-\mathrm{N} 5$ & $86.6(2)$ \\
\hline $\mathrm{C} 18-\mathrm{N} 2-\mathrm{C} 1-\mathrm{C} 2$ & $2.4(3)$ & $\mathrm{N} 1-\mathrm{C} 8-\mathrm{C} 9-\mathrm{C} 10$ & $-92.1(3)$ \\
\hline $\mathrm{C} 7-\mathrm{N} 2-\mathrm{C} 1-\mathrm{C} 6$ & $-1.9(2)$ & $\mathrm{N} 4-\mathrm{N} 3-\mathrm{C} 10-\mathrm{C} 9$ & $0.9(3)$ \\
\hline $\mathrm{C} 18-\mathrm{N} 2-\mathrm{C} 1-\mathrm{C} 6$ & $-175.07(17)$ & $\mathrm{N} 5-\mathrm{C} 9-\mathrm{C} 10-\mathrm{N} 3$ & $-0.7(2)$ \\
\hline $\mathrm{N} 2-\mathrm{C} 1-\mathrm{C} 2-\mathrm{C} 3$ & $-177.86(19)$ & $\mathrm{C} 8-\mathrm{C} 9-\mathrm{C} 10-\mathrm{N} 3$ & $178.24(19)$ \\
\hline $\mathrm{C} 6-\mathrm{C} 1-\mathrm{C} 2-\mathrm{C} 3$ & $-0.7(3)$ & $\mathrm{N} 4-\mathrm{N} 5-\mathrm{C} 11-\mathrm{C} 12$ & $73.3(2)$ \\
\hline $\mathrm{C} 1-\mathrm{C} 2-\mathrm{C} 3-\mathrm{C} 4$ & $-0.4(3)$ & $\mathrm{C} 9-\mathrm{N} 5-\mathrm{C} 11-\mathrm{C} 12$ & $-103.4(2)$ \\
\hline $\mathrm{C} 2-\mathrm{C} 3-\mathrm{C} 4-\mathrm{C} 5$ & $1.1(3)$ & $\mathrm{N} 5-\mathrm{C} 11-\mathrm{C} 12-\mathrm{C} 13$ & $7.5(3)$ \\
\hline $\mathrm{C} 3-\mathrm{C} 4-\mathrm{C} 5-\mathrm{C} 6$ & $-0.8(3)$ & $\mathrm{N} 5-\mathrm{C} 11-\mathrm{C} 12-\mathrm{C} 17$ & $-172.44(19)$ \\
\hline $\mathrm{C} 4-\mathrm{C} 5-\mathrm{C} 6-\mathrm{C} 1$ & $-0.2(3)$ & $\mathrm{C} 17-\mathrm{C} 12-\mathrm{C} 13-\mathrm{C} 14$ & $-1.9(3)$ \\
\hline $\mathrm{C} 4-\mathrm{C} 5-\mathrm{C} 6-\mathrm{N} 1$ & $178.04(18)$ & $\mathrm{C} 11-\mathrm{C} 12-\mathrm{C} 13-\mathrm{C} 14$ & $178.1(2)$ \\
\hline $\mathrm{C} 2-\mathrm{C} 1-\mathrm{C} 6-\mathrm{C} 5$ & $1.0(3)$ & $\mathrm{C} 12-\mathrm{C} 13-\mathrm{C} 14-\mathrm{C} 15$ & $-0.6(3)$ \\
\hline $\mathrm{N} 2-\mathrm{C} 1-\mathrm{C} 6-\mathrm{C} 5$ & $178.79(17)$ & $\mathrm{C} 13-\mathrm{C} 14-\mathrm{C} 15-\mathrm{C} 16$ & $2.4(4)$ \\
\hline $\mathrm{C} 2-\mathrm{C} 1-\mathrm{C} 6-\mathrm{N} 1$ & $-177.65(17)$ & $\mathrm{C} 14-\mathrm{C} 15-\mathrm{C} 16-\mathrm{C} 17$ & $-1.7(4)$ \\
\hline $\mathrm{N} 2-\mathrm{C} 1-\mathrm{C} 6-\mathrm{N} 1$ & $0.13(19)$ & $\mathrm{C} 15-\mathrm{C} 16-\mathrm{C} 17-\mathrm{C} 12$ & $-0.8(4)$ \\
\hline $\mathrm{C} 7-\mathrm{N} 1-\mathrm{C} 6-\mathrm{C} 5$ & $-176.8(2)$ & $\mathrm{C} 13-\mathrm{C} 12-\mathrm{C} 17-\mathrm{C} 16$ & $2.6(3)$ \\
\hline $\mathrm{C} 8-\mathrm{N} 1-\mathrm{C} 6-\mathrm{C} 5$ & $-5.8(3)$ & $\mathrm{C} 11-\mathrm{C} 12-\mathrm{C} 17-\mathrm{C} 16$ & $-177.4(2)$ \\
\hline $\mathrm{C} 7-\mathrm{N} 1-\mathrm{C} 6-\mathrm{C} 1$ & $1.7(2)$ & $\mathrm{C} 7-\mathrm{N} 2-\mathrm{C} 18-\mathrm{C} 19$ & $109.6(2)$ \\
\hline $\mathrm{C} 8-\mathrm{N} 1-\mathrm{C} 6-\mathrm{C} 1$ & $172.72(16)$ & $\mathrm{C} 1-\mathrm{N} 2-\mathrm{C} 18-\mathrm{C} 19$ & $-78.2(2)$ \\
\hline $\mathrm{C} 1-\mathrm{N} 2-\mathrm{C} 7-\mathrm{O} 1$ & $-176.56(19)$ & $\mathrm{N} 2-\mathrm{C} 18-\mathrm{C} 19-\mathrm{C} 20$ & $-24.7(3)$ \\
\hline
\end{tabular}




$\begin{array}{llll}\mathrm{C} 18-\mathrm{N} 2-\mathrm{C} 7-\mathrm{O} 1 & -3.2(3) & \mathrm{N} 2-\mathrm{C} 18-\mathrm{C} 19-\mathrm{C} 24 & 158.15(18) \\ \mathrm{C} 1-\mathrm{N} 2-\mathrm{C} 7-\mathrm{N} 1 & 2.9(2) & \mathrm{C} 24-\mathrm{C} 19-\mathrm{C} 20-\mathrm{C} 21 & -0.8(3) \\ \mathrm{C} 18-\mathrm{N} 2-\mathrm{C} 7-\mathrm{N} 1 & 176.23(16) & \mathrm{C} 18-\mathrm{C} 19-\mathrm{C} 20-\mathrm{C} 21 & -178.0(2) \\ \mathrm{C} 6-\mathrm{N} 1-\mathrm{C} 7-\mathrm{O} 1 & 176.65(18) & \mathrm{C} 19-\mathrm{C} 20-\mathrm{C} 21-\mathrm{C} 22 & -0.2(4) \\ \mathrm{C} 8-\mathrm{N} 1-\mathrm{C} 7-\mathrm{O} 1 & 5.4(3) & \mathrm{C} 20-\mathrm{C} 21-\mathrm{C} 22-\mathrm{C} 23 & 0.7(4) \\ \mathrm{C} 6-\mathrm{N} 1-\mathrm{C} 7-\mathrm{N} 2 & -2.83(19) & \mathrm{C} 21-\mathrm{C} 22-\mathrm{C} 23-\mathrm{C} 24 & -0.1(4) \\ \mathrm{C} 8-\mathrm{N} 1-\mathrm{C} 7-\mathrm{N} 2 & -174.11(16) & \mathrm{C} 22-\mathrm{C} 23-\mathrm{C} 24-\mathrm{C} 19 & -1.0(3) \\ \mathrm{C} 7-\mathrm{N} 1-\mathrm{C} 8-\mathrm{C} 9 & -111.65(19) & \mathrm{C} 20-\mathrm{C} 19-\mathrm{C} 24-\mathrm{C} 23 & 1.4(3) \\ \mathrm{C} 6-\mathrm{N} 1-\mathrm{C} 8-\mathrm{C} 9 & 78.5(2) & \mathrm{C} 18-\mathrm{C} 19-\mathrm{C} 24-\mathrm{C} 23 & 178.7(2) \\ \mathrm{N} 4-\mathrm{N} 5-\mathrm{C} 9-\mathrm{C} 10 & 0.2(2) & & \end{array}$

Symmetry codes: (i) $x-1,-y+1 / 2, z-1 / 2$; (ii) $-x+2,-y+1,-z+2$; (iii) $x,-y+1 / 2, z-1 / 2$; (iv) $-x+1,-y+1,-z+2$; (v) $x,-y+1 / 2, z+1 / 2$; (vi) $-x+1,-y+1,-z+1$; (vii) $-x+2,-y+1,-z+1$; (viii) $-x+1, y+1 / 2,-z+3 / 2$; (ix) $x-1, y, z$.

Hydrogen-bond geometry $\left(A,{ }^{\circ}\right)$

$\mathrm{Cg}$ is the centroid of the triazole ring $C(\mathrm{C} 9 / \mathrm{C} 10 / \mathrm{N} 3-\mathrm{N} 5)$.

\begin{tabular}{lllll}
\hline$D-\mathrm{H} \cdots A$ & $D-\mathrm{H}$ & $\mathrm{H} \cdots A$ & $D \cdots A$ & $D-\mathrm{H} \cdots A$ \\
\hline $\mathrm{O} 2-\mathrm{H} 2 A \cdots \mathrm{N} 3$ & 0.87 & 2.04 & $2.892(2)$ & 166 \\
$\mathrm{O} 2-\mathrm{H} 2 B \cdots \mathrm{O} 1^{\mathrm{i}}$ & 0.87 & 2.00 & $2.865(2)$ & 176 \\
$\mathrm{C} 10-\mathrm{H} 10 \cdots \mathrm{O} 2^{\mathrm{v}}$ & 0.95 & 2.48 & $3.402(3)$ & 164 \\
$\mathrm{C} 13-\mathrm{H} 13 \cdots C g$ & 0.95 & 2.83 & $3.451(3)$ & 124 \\
\hline
\end{tabular}

Symmetry codes: (i) $x-1,-y+1 / 2, z-1 / 2$; (v) $x,-y+1 / 2, z+1 / 2$. 